\title{
A Review on Microorganisms-Derived Products as Potential Antimicrobial Agents
}

\author{
Alka Rani ${ }^{1 *}$, Khem Chand Saini ${ }^{1 *}$, Felix Bast ${ }^{1 *}$, Sunita Varjani ${ }^{2}$, Sanjeet Mehariya ${ }^{3 *}$, Shashi Kant Bhatia ${ }^{4 *}$, Neeta \\ Sharma ${ }^{5}$, Christiane Funk ${ }^{3}$
}

1 Department of Botany, School of Basic and Applied Sciences, Central University of Punjab, Ghudda, Bathinda, 151401, Punjab, India -; alkaraniraj@gmail.com (A.R.); ksaini523@gmail.com (K.C.S.); felix.bast@gmail.com (F.B.)

2 Gujarat Pollution Control Board, Gandhinagar, 382 010, Gujarat, India; drsvs18@gmail.com (S.V.)

3 Department of Chemistry, Umeå University, 90187 Umeå, Sweden; sanjeet.mehariya@umu.se (S.M.); christiane.funk@umu.se (C.F.)

4 Department of Biological Engineering, College of Engineering, Konkuk University, Seoul 05029, Korea; shashikonkukuni@konkuk.ac.kr (S.K.B.)

5 ENEA, Italian National Agency for New Technologies, Energy and Sustainable Economic Development, Department of Sustainability-CR Trisaia, SS Jonica 106, km $419+500,75026$ Rotondella (MT), Italy; neeta.sharma@enea.it (N.S.)

\# These authors contributed equally to this work.

*Correspondence: $\quad$ felix.bast@gmail.com; sanjeet.mehariya@umu.se; $\quad$ shashikonkukuni@konkuk.ac.kr

Simple Summary: The current manuscript reviewed the microbial metabolites, including growth hormones, pigments, antibiotics, etc., that have become significant sources for life-saving drugs to combat the issues of multi-drug resistance by activating particular target sites. Thereby, they can be an attentive source for biotechnological applications, specifically for pharmaceuticals and nutraceuticals. Apart from plants, we briefly highlighted the various microorganisms, including bacteria, actinomycete, fungi, mushroom, microalgae, etc., as a well-acknowledged source to produce extensive biocontrol metabolites that are generally regarded as safe (GRAS). Such antimicrobial agents are actively used in the food, feed, agriculture, cosmetics, and pharmaceutical industries.

\begin{abstract}
Microorganisms including actinomycetes, archaea, bacteria, fungi, yeast, and micro algae are the auspicious source of vital bioactive compounds. In this review, the existing state of the art regarding antimicrobial molecules from microorganisms has been summarized. The potential antimicrobial compounds from actinomycetes, particularly Streptomyces sp.; archaea; fungi including endophytic and marine-derived fungi, mushroom; yeast, and microalgae were briefly described. Furthermore, this review briefly summarized the activity and mode of action of bacteriocins, a ribosomally synthesized antimicrobial peptides product of Eurotium sp., Streptomyces parvulus, S. thermophiles, Lactococcus lactis, etc. Bacteriocins have inherent properties such as targeting multiple-drug resistant pathogens, which allows them to be considered next-generation antibiotics. Similarly, Glarea lozoyensis derived antifungal lipohexpeptides i.e., pneumocandins, inhibits 1,3- $\beta$-glucan synthase of the fungal cell wall and acts as a precursor for the synthesis of caspofungin, is also elaborated. In conclusion, this review highlights the possibility of using microorganisms as an antimicrobial resource for biotechnological, nutraceutical, and pharmaceutical applications. However, more investigations are still required to separate, purify, and characterize these bioactive compounds and transfer these primary drugs into clinically approved antibiotics.
\end{abstract}

Keywords: Antimicrobial; bacteriocins; halocin; Chlorellin; killer yeast. 


\section{Introduction}

For the last few decades, antibiotics have saved millions of lives but the prevalence of multidrug resistance (MDR) microbial strains, nullifying the effects of antibiotics are the expected consequences of antibiotics abuse. The emergence and prevalence of antibiotic-resistant microbial strains remain one of the major health issues of the 21st century, creating selective pressure on natural microbiota. The ESKAPE pathogens (Enterococcus faecium, Staphylococcus aureus, Klebsiella pneumoniae, Acinetobacter baumannii, Pseudomonas aeruginosa, and Enterobacter species) are one of the greatest challenges in medical practices as most of them are multidrug-resistant isolates [1]. The US Centres for Disease Control and Prevention (CDC) classified the most concerning antimicrobial resistance (AMR) threats, cataloging carbapenem-resistant $P$. aeruginosa, Clostridium difficile, and A. baumannii; MDR Neisseria gonorrhoeae and carbapenem- and cephalosporin-resistant Enterobacteriaceae as "urgent" threats [2], requiring urgent measures to cope up the situation. Pendleton et al. [3] provide a contemporary summary and clinically relevant information on the ESKAPE pathogens. In contrast, the detailed description regarding the antimicrobial resistance mechanisms of ESKAPE pathogens was illustrated by Santajit and Indrawattana [1], which can be used as a tool and applied to emerging MDR pathogens. Mulani et al. [4] highlight the use of therapies, including the combination of antibiotics, bacteriophages, antimicrobial peptides, nanomedicines, and photodynamic light therapy to overcome the limitations of individual therapy. These advanced and combinatorial therapies could be used as an alternate solution to combat AMR.

Due to increased consumption of livestock products in middle-income countries, antimicrobial consumption will increase up to $67 \%$, and up to two-fold in India, Brazil, China, Russia, and South Africa, by 2030 [5]. However, the approval of antibacterial agents decreased by $56 \%$ from 1998 to 2002 as compared to the period from 1983 to 1987, and out of total 225 new molecular entities, only $3 \%$ of antimicrobial agents were approved by the United States Food and Drug Administration (FDA) from 1983 to 2002. FDA approved 6 novel antibacterial drugs, including the $3^{\text {rd }}$ generation cephalosporin and $\beta$ lactamase inhibitor combination ceftazidime/avibactam, in 2015 [6], whereas in 2018 and 2020, not a single antimicrobial drug had been approved by FDA [7].

The current review summarizes the microbial metabolites, including growth hormones, pigments, antibiotics, etc., that have become significant sources for life-saving drugs. Many of these microbial metabolites hold specific antimicrobial potential and act at particular target sites (Figure 1); thereby, they can be an attentive source for biotechnological applications, specifically for pharmaceuticals and nutraceuticals [8]. During the late 1980s, a shift from chemical synthesis of drug discovery from nature to the laboratory bench has taken place, resulting in the discovery of approximately $50 \%$ natural drugs from 1981 to 2010 [9]. Prodigiosin, an antimicrobial pigment produced by the marine bacterium Vibrio ruber, induces autolytic activity in the Bacillus subtilis. Similarly, Lantibiotics from Gram-positive bacteria were bioengineered to increase their effectiveness against a wide range of bacterial strains and improve their stability while transmitting through the gastrointestinal (GI) tract making them protease-resistant [10].

Biofilms formed by bacteria are ubiquitous and are a part of their survival mechanisms. Biofilms have been involved in many clinical infections such as atherosclerosis, pharyngitis, laryngitis, pertussis, bacterial vaginosis, etc. [11]. Apart from causing deadly infections and diseases, bacterial antimicrobial compounds are reported as antifungal, antiviral, etc., as described in this review. We briefly highlighted the bacteriocins from lactic acid bacteria (LAB) and their mode of action. Most antimicrobials disrupt the cell membrane integrity or inhibit cell wall synthesis, protein, and nucleic acid synthesis. A recent study by Ting et al. [12] updated the epidemiology of the infectious keratitis (IK), the leading cause of corneal blindness; its causative microorganisms including bacteria, virus, fungi, parasites, and polymicrobial infections; major risk factors associated with IK and the impact of AMR on the treatment of IK. Antimicrobial compounds such as vinaceuline, bafilomycin, antimycin, and other anti-methicillin-resistant S. aureus (MRSA) compounds 
synthesized by Streptomyces sp., having antagonistic activity against different microbial strains are discussed in the present review. We also elaborated on the halocins and sulfolobicin from archaea. Further, the antimicrobials reported from endophytic and marinederived fungi along with mushrooms, yeasts, and microalgae are summarized. Microalgae act as a potential source of antimicrobial substances due to the synthesis of indoles, acetogenins, terpenes, phenols, and volatile halogenated hydrocarbons, which have also been discussed. Hence this review documented the potential antimicrobial compounds discovered from the all-possible microbial resources, including microbes inhabiting extreme habitats.

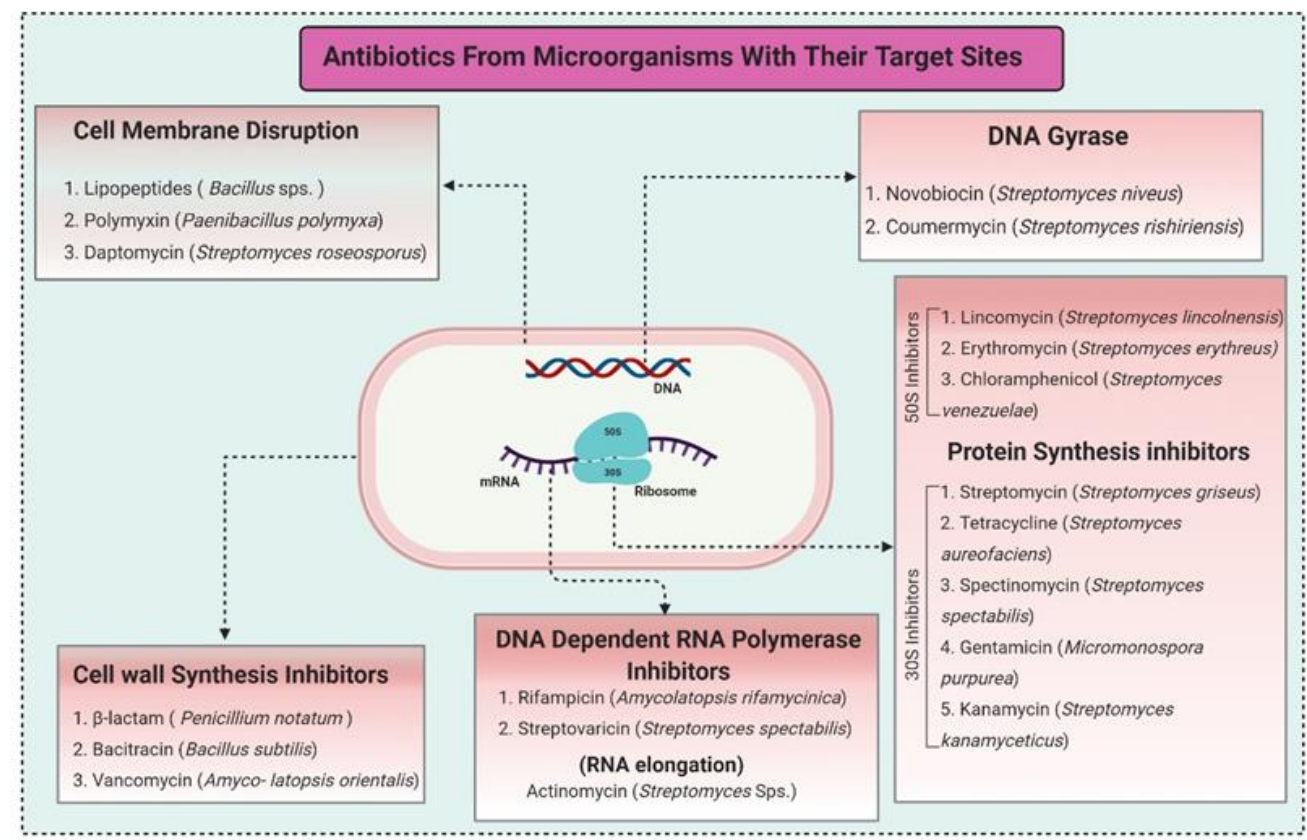

Figure 1. Antibiotics reported from different microorganisms with their target sites.

\section{Bacteria}

Bacterial antimicrobial compounds have been used traditionally for numerous reasons, including delaying the spoilage of food material or crops by plant pathogens in agriculture and extending the shelf life of products in the food industry [13]. Bacillus strains are well-acknowledged to produce extensive biocontrol metabolites, which include the ribosomally synthesized antimicrobial peptides (bacteriocins) [14], as well as non-ribosomally synthesized peptides (NRPs) and polyketides (PKs) [15].

\subsection{Ribosomally synthesized antimicrobial peptides (bacteriocins) and bacteriocin-like inhibitory substances (BLIS):}

Bacteriocins are antimicrobial ribosomal peptides reported from all major lineages of bacteria and some members of archaea. Gram-negative bacteria Escherichia coli produces colicins that are bacteriocidal protein, which is larger than $20 \mathrm{kDa}$ and prevents the growth of closely related strains [16]. Bacteriocins have attracted more attention because of their impending use as a usual food preservative and therapeutic antibiotic. Another reason is that they have a rapid-acting mechanism by forming pores in the membrane of target bacterial cells, even at very low concentrations (Figure 2). The recently reported bacteriocins along with their characteristics are presented in Table 1. Bacteriocins from lactic acid bacteria (LAB) have gained significant attention due to their food-grade quality and industrial significance. LAB and its by-products are generally regarded as safe (GRAS) as a human food component by the U.S. Food and Drug Administration (FDA). Hence it is safer to use LAB bacteriocin to constrain the growth of pathogenic/undesirable bacteria [17]. Lozo et al. [18] isolated the strain Lactobacillus paracasei from customarily homemade 
white-pickled cheese and reported that it produces bacteriocin 217 (Bac217), exhibiting antimicrobial activity against Pseudomonas aeruginosa, Bacillus cereus, Salmonella sp., and S. aureus.

A study by Drissi et al. [19] suggests that bacteriocins are widespread across the human GI tract, with 317 microbial genomes encoding maximum bacteriocins of classes I $(44 \%)$ as compared to class II (38.6\%) and III (17.3\%). Further, they elaborated the bacteriocins produced by gut microbiota, i.e., Class I bacteriocins display low antimicrobial activity. Whereas maximum class II bacteriocins were reported from bacteria not occurring in the gut. Similarly, Leite et al. [20] described BLIS produced by Bacillus cereus LFB-FIOCRUZ 1640, with activity against Listeria monocytoges and other Bacillus species in pineapple pulp and can be used as a potential food bio preservative. Also, Choeisoongnern et al. [21] reported that BLIS produced by Pediococcus pentosaceus, and Enterococcus faecium from fermented food inhibits the growth of Carnobacterium maltraromaticum, Candida albicans, Listeria ivanovii, Listeria innocula, Pseudomonasc aeruginosa, Streptococcus mutans, and S. aureus. More recently, Pircalabioru et al. [22] comprehensively reviewed bacteriocins' potential as an antimicrobial agent against infections mainly due to resistant pathogens i.e., MRSA. In contrast, Jawan et al. [23] suggest that BLIS from Lactococcus lactis Gh1 inhibits the growth of Listeria monocytogenes and can be used in the food industries as functional foods for the preparation of starter culture and probiotic products. In addition, BLIS from B. subtilis BSC35 inhibits Clostridium perfringens; therefore, it can be used to control C. perfringens in fermented foods [24].

Unfortunately, many factors cause a reduction in BLIS antimicrobial activity affecting the efficacy of bacteriocins. Such factors include the advent of bacteriocin-resistant strains, conditions that were destabilizing its biological activities such as oxidation processes, poor solubility, proteases or inactivation by other additives, and $\mathrm{pH}$ or temperature. Therefore, it is necessary to develop such a system that minimizes these drawbacks and maximizes bacteriocins' bioprotective potential.

Table 1. List of recently reported Bacteriocins (ND: not determined).

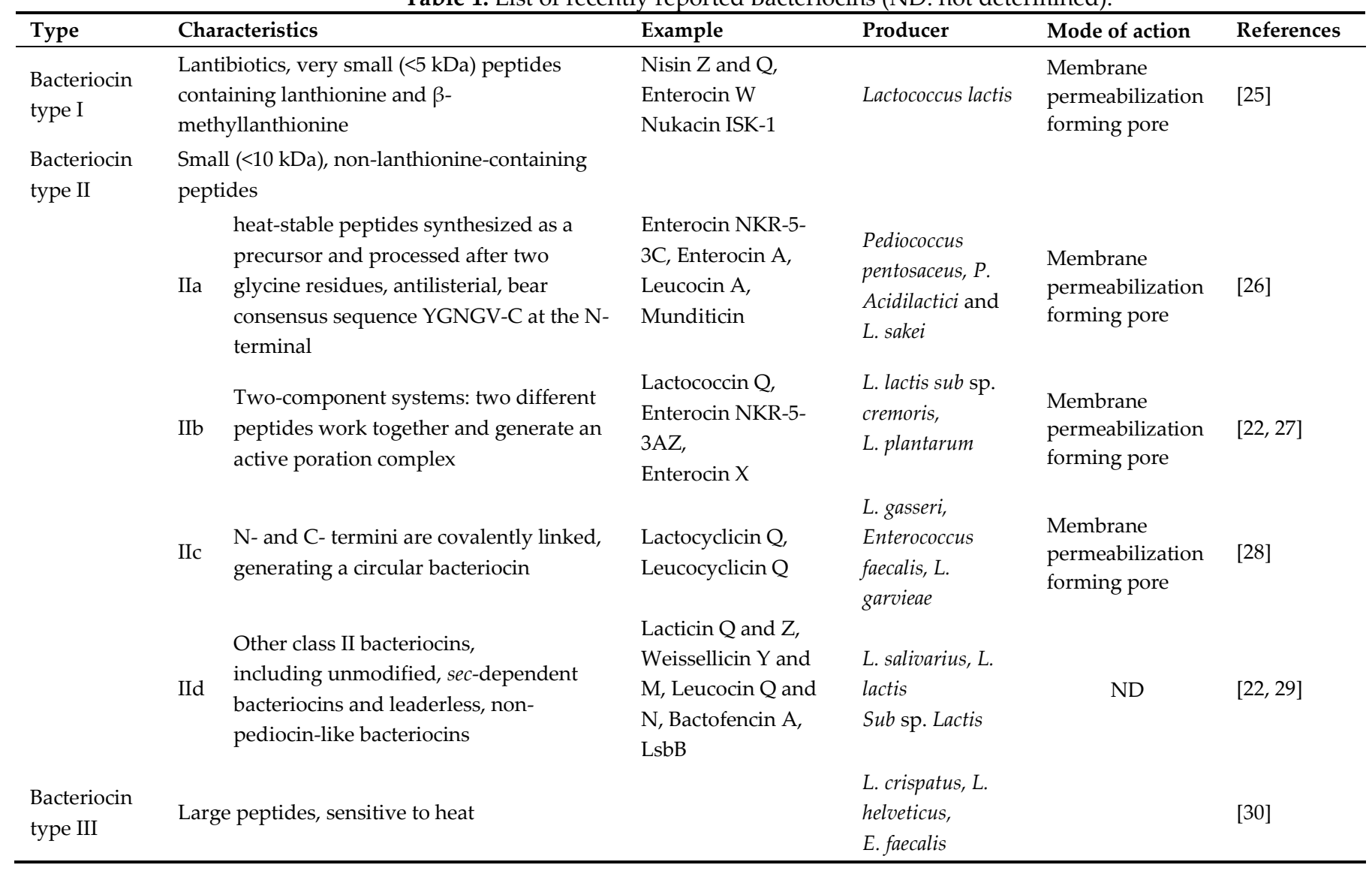


IIIa $27 \mathrm{kDa}$, heat-labile protein

$\mathrm{IIIb}$

\begin{abstract}
Lysostaphin and
enterolysin A
\end{abstract}

Helveticin J

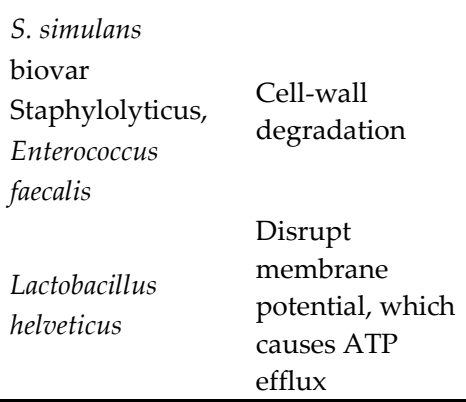

Nisin belongs to type I bacteriocin and is the first antimicrobial peptide from Lactococcus and Streptococcus sp. and has been regarded as GRAS by both FDA and WHO [33]. Nisin has been used to inhibit microbial growth in beef, ground beef, sausages, liquid whole eggs, and poultry. It was reported that when nisin was cross-linked to chitosan, minimum inhibitory concentration (MIC) decreased from $48 \mu \mathrm{g} / \mathrm{ml}$ to $40 \mu \mathrm{g} / \mathrm{ml}$ for Staphylococcus aureus ATCC6538. Antimicrobial activity of nisin was increased after crosslinking with a lesser concentration of chitosan i.e., the ratio of 200:1, thereby allowing better penetration into the lipid membrane [34]. The antibacterial constancy of nisin was successfully enhanced after its conjugation with gellan. The gellan-nisin conjugate was able to tolerate a broad range of $\mathrm{pH}$ and temperature, and also its antibacterial duration against Staphylococcus epidermidis was improved from $48 \mathrm{~h}$ to $144 \mathrm{~h}$ under alkaline environments and from $96 \mathrm{~h}$ to $216 \mathrm{~h}$ under acidic conditions. Therefore this conjugate can be an encouraging biomaterial for wound dressings and transplant coatings [35]. Heunis et al. [36] stated that the application of nisin-coated wound dressing prevented S. aureus' colonization and quickened the healing procedure. A study revealed the proficiency of nisin in combination with polymyxin in combating $P$. aeruginosa biofilms and reduced the dose of polymyxin required to interrupt $P$. aeruginosa biofilms [37]. Possibly polymyxin might facilitate the transfer of nisin to its target. Along with nisin's synergistic action with polymyxin and clarithromycin against $P$. aeruginos $a$ and other non- $\beta$-lactam antibiotics against MRSA [38] and strains of vancomycin-resistant enterococci [39] was also reported. Webber et al. [40] embedded $0.89 \mu \mathrm{g} \mathrm{cm}^{-2}$, positively charged nisin $\mathrm{Z}$ within polyelectrolyte multilayers (PEMs) i.e., 9 layers of carrageenan (CAR) and chitosan (CS), forming a 4.5 bilayer film with antimicrobial activity against $S$. aureus and MRSA. Therefore, the antimicrobial potential of CAR/CS multilayers helps in realizing its applicability within food, pharmaceutical, and biomedical industries [40]. Apart from bacteria, nisin also inhibits fungal growth (i.e., Candida albicans). Though nisin has a broad range of biomedical applications and is used in food bio preservation yet further justification of nisin's practicality and evaluation of its efficacy in biomedical fields will require in vivo and in vitro studies.

Bacteriocins in Gram-positive bacteria follow two possible mechanisms, as shown in Figure 2 . 


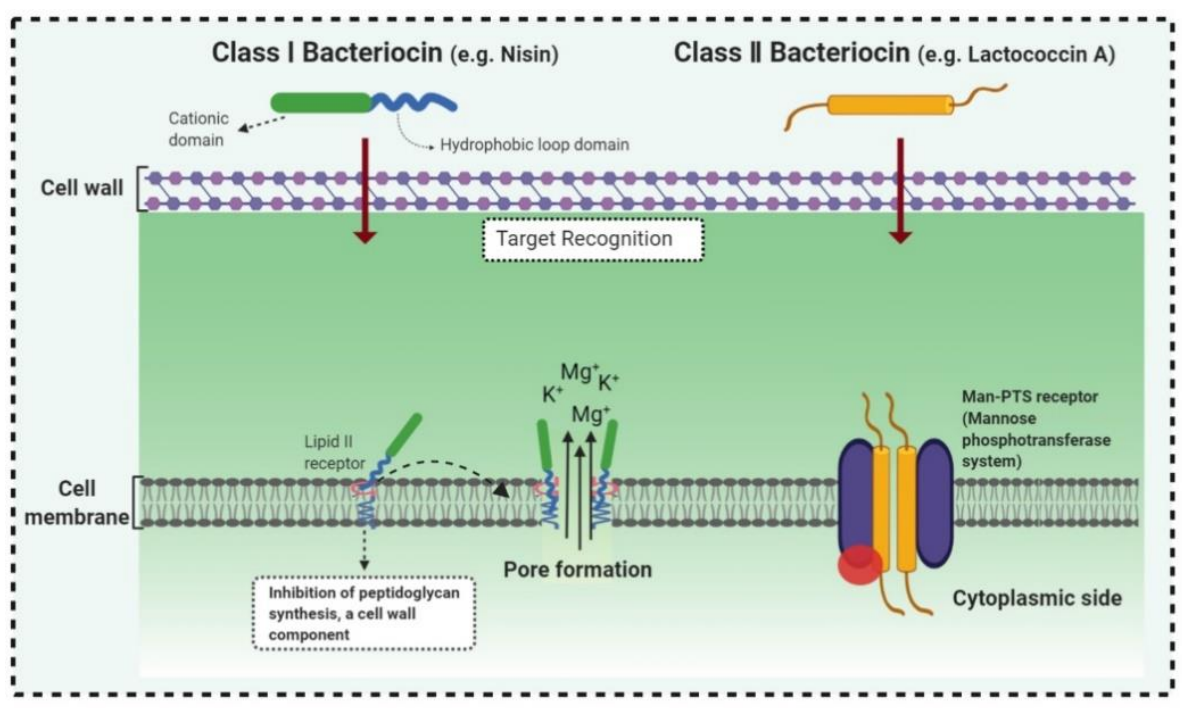

Figure 2. Mode of action of bacteriocins via the dual mechanism. (a) inhibition of cell wall synthesis: Class II bacteriocins (e.g., lactococcin), cross the cell wall and bind with the pore-forming receptor in the mannose-phosphotransferase (man-PTS), resulting in the pore formation in the cell membrane. (b) pore formation: Class I bacteriocins, (e.g., nisin) can follow both mechanisms. Nisin generated pores in the cell membrane resulting in the efflux of ions $\left(\mathrm{K}^{+}\right.$and $\left.\mathrm{Mg}^{2+}\right)$, amino acids (glutamic acid, lysin), generating proton motive force dissipation and ultimately cause cell death.

Class I bacteriocins are cationic lantibiotic (e.g., nisin) that electrostatically binds with the negatively charged membrane phospholipids II, allowing further interaction of bacteriocin's hydrophobic domain with the target cytoplasmic membrane (lipid II), thereby preventing the biosynthesis of peptidoglycan [22, 41-42].

\subsection{Non-ribosomal synthesized peptides (NRPs) and polyketides (PKs):}

NRPs and PKs include a range of cyclic, linear, and branched compounds, synthesized by composite enzymes viz. non-ribosomal peptide synthetases (NRPS), polyketide synthetases (PKS), and hybrid of NRPS/PKS, respectively [15, 43]. Lipopeptides (LPs) are NRPs produced by Bacillales, have significant antimicrobial activity [44]. LAB is considered the primary producer of ribosomally synthesized antimicrobial peptides, as reviewed by Alvarez-Sieiro et al. [45] and Pircalabioru et al. [22]. However, the classification scheme for antimicrobial compounds produced by Bacillus is not explored as compared to LAB. Caulier et al. [15] reviewed and updated the antimicrobial metabolites classification from the B. subtilis group based on the biosynthetic pathway and chemical nature. Zhao et al. [14] acknowledged 31 types of PKs, NRPs, and NRPS/PKS hybrid synthesized antimicrobials using antiSMASH.

\subsection{Lipopeptides (LPs):}

LPs occur naturally and are of bacterial origin, contain a hydrophobic long alkyl chain that associates with a hydrophilic polypeptide, and forms a cyclic or linear structure [46]. Traditional LPs including the iturins, surfactins, and fengycins (Table 2) produced from Bacillus species and are homologs that differ in length, branching pattern, and saturation of their acyl chain. LPs comprise anionic (e.g., surfactin and daptomycin) or cationic (e.g., colistin and polymixin B) peptide motif, dictating the range of its activity. As demonstrated by Perez et al. [47] Bacillus sp. P5 synthesize LPs iturin A, bacteriocin subtilosin A and surfactin exhibiting antimicrobial activity against Listeria monocytogenes and Bacillus cereus, along with the antifungal activity. A study by Kourmentza et al. [48] reported that a mixture of mycosubtilin and mycosubtilin/surfactin LPs inhibits the growth of 
filamentous fungi Byssochlamys fulva and Paecilomyces variotti, with MICs of 1-16 mg/L and Candida krusei with MIC of 16-64 mg/L.

Table 2: Various types of LPs with their characteristics.

\begin{tabular}{|c|c|c|c|c|c|c|}
\hline Type & $\begin{array}{l}\text { Characteristics } \\
\text { features }\end{array}$ & $\begin{array}{l}\text { Molecular } \\
\text { weight }\end{array}$ & Chemical structure & Producer & Applicability & References \\
\hline Surfactin & $\begin{array}{l}\text { Cyclic heptapep- } \\
\text { tide is an antibi- } \\
\text { otic with seven } \\
\text { amino acids i.e., } \\
\text { Glu-Leu-Leu-Val- } \\
\text { Asp-LeuLeu } \\
\text { (ELLVDLL). } \\
\text { A, B, and C types } \\
\text { varying accord- } \\
\text { ing to their amino } \\
\text { acid sequences. }\end{array}$ & $\sim 1.03 \mathrm{kDa}$ & & $\begin{array}{l}\text { B. subtilis MSH1 and } B \text {. } \\
\text { amyloliquefaciens } \text { ES-2 }\end{array}$ & $\begin{array}{l}\text { Antimicrobial, } \\
\text { antifungal, insec- } \\
\text { ticidal, antimy- } \\
\text { coplasma, } \\
\text { hemolysis, and } \\
\text { formation of ion } \\
\text { channels in lipid } \\
\text { membranes. }\end{array}$ & [49] \\
\hline Iturin & $\begin{array}{l}\text { Contains two ma- } \\
\text { jor parts: a pep- } \\
\text { tide part com- } \\
\text { posed of } 7 \text { amino } \\
\text { acid residues } \\
\text { (Asn-Tyr-Asn- } \\
\text { Gln-Pro-Asn-Ser) } \\
\text { and } 11-12 \text { carbons } \\
\text { hydrophobic tail. } \\
\text { Example Iturin A, } \\
\text { Bacillomycin D, } \\
\text { Bacillomycin L, } \\
\text { Mycosubtilin }\end{array}$ & $\sim 1.04 \mathrm{kDa}$ & & $\begin{array}{l}\text { B. subtilis, B. amylolique- } \\
\text { faciens B128 and B. amy- } \\
\text { loliquefaciens BUZ-14 }\end{array}$ & $\begin{array}{l}\text { Antimicrobial } \\
\text { and antifungal } \\
\text { activities. Dis- } \\
\text { rupt the mem- } \\
\text { brane of yeast } \\
\text { cells by increas- } \\
\text { ing the electrical } \\
\text { conductance of } \\
\text { bimolecular lipid } \\
\text { membranes. }\end{array}$ & [50] \\
\hline Fengycin & $\begin{array}{l}\text { An array of } 10 \\
\text { amino acids with } \\
\text { a lactone ring and } \\
\text { a B-hydroxy fatty } \\
\text { acid linked to the } \\
\text { N-terminus of a } \\
\text { decapeptide. Ex- } \\
\text { ample Plipastatin } \\
\text { A and B }\end{array}$ & $\begin{array}{l}1463.7 \\
\mathrm{~g} / \mathrm{mol}\end{array}$ & & B. subtilis & $\begin{array}{l}\text { Act as bioagents } \\
\text { showing hypo- } \\
\text { cholesterolemic } \\
\text { activities, im- } \\
\text { muno-modula- } \\
\text { tors; antibiotics, } \\
\text { antiviral, and an- } \\
\text { titumor agents; } \\
\text { toxins; and en- } \\
\text { zyme inhibitors }\end{array}$ & [51] \\
\hline
\end{tabular}

Surfactins, a cyclic heptapeptide that formulates a lactone bridge with $\beta$-hydroxy fatty acids, are the most potent biosurfactant. It displays an array of activities including hemolytic, antiviral, anti-mycoplasma, and antibacterial [52]. Surfactin WH1 fungin from Bacillus amyloliquefaciens WH1 is an antifungal inhibiting glucan synthase that reduces the synthesis of callose on the fungal cell wall and binds to ATPase on the mitochondrial membrane ultimately inducing apoptotic markers to stimulate the extracellular apoptotic pathway [53]. Many researchers claim that after inserting into the lipid bilayers, surfactin acts by forming voltage-independent channels in biofilms, distorting the membrane integrity and permeability of ions, i.e., $\mathrm{K}^{+}$and $\mathrm{Ca}^{2+}$, causing membrane disruption [54].

Iturins comprises A, C, D, and E isoforms, bacillomycin D, F and L, and mycosubtilin that inhibit bacterial growth in the same manner as Class I and Class II bacteriocins [55], whereas mycosubtilin modifies the plasma membrane permeability, thereby liberating nucleotides, proteins, and lipids from the cell [56]. A marine-derived Bacillus velezensis 115 produced a cyclic lipopeptide (CLP) iturin A, considered an antagonist against Magnaporthe oryzae, a rice pathogen [57].

Fengycin, an anti-fungal lipopeptide, isolated from Bacillus sp. is also called plipastatin. Its isoforms fengycin A and fengycin B vary in the single amino acid at the sixth position (D-alanine and D-valine, respectively) [58]. Both iturins and fengycins act as 
biocontrol agents preventing plant diseases and inhibiting the progression of a wide variety of plant fungal pathogens including Aspergillus flavus, Rhizoctonia solani, Fusarium graminearum, Botritis cinerea, and Penicillium expansum [59].

Kurstakins are cyclic heptalipopeptides [60], whereas cerexins are linear LPs [61], and both are isolated from Bacillus thuringiensis and Bacillus cereus respectively. Cerexins are active against $S$. aureus and Streptococcus pneumoniae [62]. Octapeptins, cationic peptides produced by Bacillus sp. and Paenibacillus sp., have antimicrobial activity, inhibiting filamentous fungi, yeasts, and protozoa along with some Gram-positive and Gram-negative bacteria by disrupting the cytoplasmic membrane [63].

However, no doubt LPs are a novel class of antibiotics exhibiting a wide range of activities. Therefore, detailed structural and functional knowledge is required to exploit these LPs as antibiotics, anti-tumor agents, antimicrobials, feed additives, and drug delivery systems.

\section{Actinomycetes}

The actinomycetes are Gram-positive, aerobic, filamentous, and spore-forming bacteria, with a foremost reputation for producing chemically different metabolites bearing a broad spectrum of biological activities, including antifungal, antibacterial, and insecticidal activities. Approximately $75 \%$ of the known industrial antibiotics and economically important compounds were obtained from the Streptomyces species [64]. Actinobacteria can synthesize antifungal, antiviral, antitumor, anti-inflammatory, antioxidants, immunosuppressive, plant-growth-promoting, and herbicidal compounds [65]. Among actinobacteria, Streptomyces is the utmost and dominant because of a broad range of bioactive metabolites. The genus Streptomyces alone contributes approximately 7500 compounds among the 10,000 known compounds from actinobacteria, whereas the other genera including Actinomadura, Micromonospora, Nocardia, Saccharopolyspora, Actinoplanes and Streptosporangium contributes approximately 2500 compounds [66]. Marine or terrestrial actinobacteria utilize enzymes polyketide synthases (PKS) or non-ribosomal peptide synthetases (NRPS) for the synthesis of metabolic bioactive compounds [67].

Widowati et al. [68] reported a new strain of marine actinomycetes, NPS12745 associated with marine sediment from the coast of San Diego, California, and after using 16S rRNA gene sequencing, NPS12745 was confirmed as an innovative strain of genus Marinispora, which produced ample new chlorinated bisindole pyrroles and their derivatives including chromopyrrolic acid, which was earlier isolated from Chromobacterium violaceum. The first halogenated bisindole derivative was lynamicins A-E, having activity against several Gram-positive and Gram-negative bacteria, i.e., MSSA (methicillin-susceptible Staphylococcus aureus), MRSA, S. epidermidis, and Enterococcus faecalis, signifying possible cure of nosocomial infections [69]. Siddharth and Vittal (2018) isolated Streptomyces sp. S2A from marine sediment from the Gulf of Mannar, with persuasive antagonistic activity against bacterial (Micrococcus luteus, S. epidermidis, Klebsiella pneumoniae, Bacillus cereus, and S. aureus) and fungal (Fusarium moniliforme and Bipolaris maydis) pathogens [66]. Igarashi et al. [70] reported Maklamicin, a novel spirotetronate of class polyketide from an endophytic actinomycete Micromonospora sp. GMKU326, inhibiting Micrococcus luteus, B. subtilis, S. aureus, B. cereus, and Enterococcus faecalis, Gram-positive bacteria with minimum inhibitory concentrations (MICs) of $0.2,1.7,13,6.5$, and $13 \mu \mathrm{g} / \mathrm{ml}$ respectively. A unique prenylated-indole derivative known as 3-acetonylidene-7- prenylindolin-2-one, hybrid isoprenoids, 3-cyanomethyl-6-prenylindole, 7-isoprenylindole-3-carboxylic acid, and 6-isoprenylindole-3-carboxylic acid were extracted from the Streptomyces sp. neauD50. These antifungal compounds prevent the growth of phytopathogenic fungi Corynespora cassiicola, Phytophthora capsica, Colletotrichum orbiculare, and Fusarium oxysporum [71]. Djinni et al. [72] described Streptomyces sundarbansensis WR1L1S8, an endophyte sequestered from brown algae yields an innovative anti-MRSA compound, [2-hydroxy-5-((6-hydroxy-4-oxo-4H-pyran-2-yl)methyl)-2-ropylchroman-4-one] beside three 
already reported polyketides namely phaeochromycin B, C, and E which are active against Gram-positive pathogenic MRSA.

Yang et al. [73] isolate vinaceuline, a cyclopeptide, activity against bacteria, from the broth culture of endophytic Streptomyces sp. YIM64018 allied with Paraboea sinensis. The same team isolated a new benzamide, 2-amino-3, 4-dihydroxy-5-methoxybenzamide in 2015, from Streptomyces YIM67086 that attacks E. coli and Candida albicans (MICs of 64 and $32 \mu \mathrm{g} / \mathrm{ml}$, respectively). Ding et al. [74] reported 7, 3'-di-(c,c dimethylallyloxy)-5-hydroxy40-methoxyflavone, a novel antifungal compound, from the broth culture of Streptomyces sp. MA-12 obstructs the growth of plant pathogens Penicillium citrinum, Gibberella zeae, and Colletotrichum musae.

Lee et al. [75] isolated 87 actinobacterial species including a novel species Streptomyces pluripotens MUSC135T, that inhibit MRSA. This antibacterial metabolite-producing ability was confirmed by PKS (polyketide synthetase) and NRPS (non ribosomal polyketide synthetase) gene detection process. Streptomyces sp. colonizing on root tissues produce ample antifungal and antibacterial compounds i.e., antimycin A18, phaeochromycin $\mathrm{B}, \mathrm{C}$ and E, diastaphenazine, 3-acetonylidene-7-prenylindolin-2-one, and staurosporine, some of them are represented in Table 3. The unique properties of rhizospheric actinomycetes to produce a diverse range of bioactive metabolites with antagonistic outcomes toward pathogens have led them to be a potent agent ensuring plant health.

Cycloserin, an antibiotic produced by Streptomyces orchidaceus, block protein synthesis and is used to treat tuberculosis in conjugation with other drugs [84]. Robertsen and Musiol-Kroll, [85] reviewed the actinomycetes-derived polyketide drugs such as erythromycin A, tetracyclines, rifamycin, tylosin, monensin A, amphotericin B, etc. with antimicrobial activity, including the source of the compounds, their structure, the biosynthetic mechanisms, and mode of action. However, the increasing rate of MDR requires the rediscovery of compounds from potential producers. However, many organisms require special cultivation conditions, so many strategies need to be developed to overcome such barriers. Hug et al. [86] described the strategies and innovative methods such as advanced cultivation methods, genomics, metabolomics, and metagenomics-based approaches to explore the new reservoir of actinomycetes and improve the efficacy of antimicrobial compounds. 
Table 3. Bioactive compounds from endophytic actinomycetes.

\begin{tabular}{|c|c|c|c|c|c|c|}
\hline $\begin{array}{l}\text { Endophytic } \\
\text { nomycetes }\end{array}$ & Acti- & Host & Bioactive compounds & Structure & Bioactivity & Reference \\
\hline $\begin{array}{l}\text { Streptomyces } \\
\text { YIM64018 }\end{array}$ & sp. & $\begin{array}{l}\text { Paraboea sinen- } \\
\text { sis }\end{array}$ & Vinaceuline & - & Antibacterial activity & [76] \\
\hline $\begin{array}{l}\text { Streptomyces } \\
\text { neau-D50 }\end{array}$ & sp. & Glycine max & $\begin{array}{l}\text { 3-acetonylidene-7- } \\
\text { prenylindolin-2-one, 7- } \\
\text { isoprenylindole-3-car- } \\
\text { boxylic acid }\end{array}$ & & $\begin{array}{l}\text { Cytotoxic and antifungal ac- } \\
\text { tivities }\end{array}$ & [71] \\
\hline $\begin{array}{l}\text { Streptomyces } \\
\text { YIM56209 }\end{array}$ & sp. & $\begin{array}{l}\text { Drymaria cor- } \\
\text { data }\end{array}$ & $\begin{array}{l}\text { Bafilomycin D, B1, B2, } \\
\mathrm{C} 1, \mathrm{C} 2, \mathrm{C} 1 \text { amide and } \\
\mathrm{C} 2 \text { amide }\end{array}$ & & $\begin{array}{l}\text { Antibacterial, antifungal, in- } \\
\text { secticidal, antihelmintic and } \\
\text { cytotoxic activity }\end{array}$ & [87] \\
\hline $\begin{array}{l}\text { Streptomyces } \\
\text { staticus } \\
\text { Sub sp. } \\
\text { ardesiacus }\end{array}$ & dia- & $\begin{array}{l}\text { Artemisia an- } \\
\text { nua }\end{array}$ & Diastaphenazine & - & $\begin{array}{l}\text { Antibacterial and antifungal } \\
\text { activity }\end{array}$ & [78] \\
\hline $\begin{array}{l}\text { Streptomyces } \\
\text { YIM67086 }\end{array}$ & sp. & $\begin{array}{l}\text { Dysophylla stel- } \\
\text { lata }\end{array}$ & $\begin{array}{l}\text { 4-hydroxy-3-methox- } \\
\text { ybenzoic acid, p-hy- } \\
\text { droxytruxinic acid }\end{array}$ & - & Antifungal activity & [73] \\
\hline $\begin{array}{l}\text { Microbispora } \\
\text { LGMB259 }\end{array}$ & sp. & $\begin{array}{l}\text { Vochysia diver- } \\
\text { gens }\end{array}$ & $\begin{array}{l}\beta \text {-carboline or 1-vinyl- } \\
\beta \text {-carboline-3-carbox- } \\
\text { ylic acid }\end{array}$ & & $\begin{array}{l}\text { Antibacterial, antifungal } \\
\text { and anticancer activity }\end{array}$ & [79] \\
\hline $\begin{array}{l}\text { Streptomyces } \\
\text { YIM66017 }\end{array}$ & sp. & $\begin{array}{l}\text { Alpinia oxy- } \\
\text { phylla }\end{array}$ & $\begin{array}{l}\text { Yangjinhualine } \mathrm{A} \text { and } \\
\text { 2,6-dimethoxy tereph- } \\
\text { thalic acid }\end{array}$ & & Radical scavenging activity & [80] \\
\hline $\begin{array}{l}\text { Streptomyces } \\
\text { doflavus } \\
\text { 07A-01824 }\end{array}$ & albi- & $\begin{array}{l}\text { Bruguiera gym- } \\
\text { norrhiza }\end{array}$ & Antimycin A18 & & Antifungal activity & [81] \\
\hline $\begin{array}{l}\text { Streptomyces } \\
\text { VITMK1 }\end{array}$ & sp. & mangrove soil & Pyrrolopyrazines & - & Antimicrobial & [82] \\
\hline Streptomyces s & & & Diketopiperzines & - & Anti-H1N1 activity & [83] \\
\hline
\end{tabular}

\section{Archaea}

Archaeocins, is a proteinaceous antibiotic produced from archaea and mark the chronicled beginning in the series of antimicrobial compounds. The term "archaeocin" was used to differentiate the archaeal peptide and protein-based antibiotics from those produced by bacteria [88]. Only two phylogenetic groups have produced Archaeocins (Table 4); one is euryarchaeal producing "halocins" whereas the other group is crenarchaeal genus Sulfolobus producing "sulfolobicin" [89]. Valera et al. [90] reported halocins, the first proteinaceous antimicrobial compound from halophilic members of the archaeal domain. Archaeal protein VLL-28, from Sulfolobus islandicus, is the first archaeal antimicrobial peptide, possessing a broad-spectrum antibacterial and antifungal activity [91]. Until now, very few reports were available on the characterization of antimicrobial compounds from archaea. Besse et al. [92] and his team comprehensively reviewed the 
archaeocins and sulfolobicins antimicrobial peptides ribosomally-synthesized by archaea belonging to the order Halobacteriales and Sulfolobales, respectively. However, till now halocin A4, G1, R1, H1 [93]; H2 [29]; H3, H5 [90]; H4 [94]; H6 [95]; C8 [96]; S8 [97]; HalR1 [98]; and Sech7a [99] have been considered up to their molecular level, still their mode of action is not clearly understood [100]. Only some workers reported that halocins kill the indicator organisms by altering the cell permeability at membrane level followed by cell lysis. However, to date, only the mode of action mechanism of halocin $\mathrm{H} 6 / \mathrm{H} 7$ produced by Haloferax gibbonsii was characterized. HalH6 specifically inhibits $\mathrm{Na}^{+} / \mathrm{H}^{+}$antiporter and proton flux ultimately causing cell lysis and death [101].

$\mathrm{H} 1$ and $\mathrm{H} 4$ are proteinaceous halocins of roughly 30-40 kDa [102], whereas C8, H6, H7, R1, U1, and S8 are microhalocins of size smaller than 10kDa. Microhalocins are more vigorous than proteinaceous halocins since they are resistant to flexibility in temperature, salinity, exposure to organic solvents, acids, and bases [102]. Halocins have a wide-ranging activity against haloarchaea and members of the family Halobacteriaceae [103]. Mainly halocin production is prompted during the progression between exponential and stationary phases, with $\mathrm{H} 1$ being an exception, produced during the exponential phase of the growth cycle [104]. Recently, Sahli et al. [105] screened 81 halophilic strains collected from solar salterns of Algeria's northern coast for the production of antimicrobial compounds. Through partial 16S rRNA gene sequencing, these strains were recognized to belong to the Haloferax $(H f x)$ sp.

Table 4. Archaeocins reported from halobacteria (ND: not determined).

\begin{tabular}{|c|c|c|c|c|c|c|}
\hline Halocin & Producers & Size (kDa) & Origin & Active against & Mode of action & Reference \\
\hline HalH1 & $\begin{array}{l}\text { Haloferax mediter- } \\
\text { ranei Xia3 }\end{array}$ & 31 & $\begin{array}{l}\text { Solar salterns, } \\
\text { Alicante, Spain }\end{array}$ & $\begin{array}{l}\text { Members of the } \\
\text { Halobacteriales }\end{array}$ & Alter membrane permeability & [92] \\
\hline HalH4 & $\begin{array}{l}\text { Hfx. mediterranei } \\
\text { R4 }\end{array}$ & 34.9 & $\begin{array}{l}\text { Solar salterns, } \\
\text { Tunisia }\end{array}$ & $\begin{array}{l}\text { Members of the Ha- } \\
\text { lobacteriales, } \\
\text { Strains of Sulfolobus } \\
\text { sp. }\end{array}$ & $\begin{array}{c}\text { Alter macromolecular synthesis, } \\
\text { cell wall conformation, and } \mathrm{Na}+ \\
\qquad / \mathrm{H}+\text { antiport inhibitor }\end{array}$ & [106] \\
\hline HalH6 & $\begin{array}{l}\text { Hfx. } \\
\text { Ma2.39 }\end{array}$ & 32 & $\begin{array}{l}\text { Solar salterns, } \\
\text { Alicante, Spain }\end{array}$ & $\begin{array}{l}\text { Members of the } \\
\text { Halobacteriales }\end{array}$ & $\begin{array}{l}\text { Alter intracellular osmotic bal- } \\
\text { ance, } \mathrm{Na}+/ \mathrm{H}+\text { antiport inhibitor }\end{array}$ & [92] \\
\hline HalS8 & $\begin{array}{l}\text { Haloarchaeal } \\
\text { strain S8a, Halobac- } \\
\text { terium sa- } \\
\text { linarum strain } \\
\text { ETD5 }\end{array}$ & 3.58 & $\begin{array}{l}\text { Great Salt Lake, } \\
\text { (Utah, United } \\
\text { States) }\end{array}$ & $\begin{array}{l}\text { Halobacterium sa- } \\
\text { linarum NRC817, } \\
\text { Hbt. sp. strain GRB } \\
\text { and Hfx. gibbonsii }\end{array}$ & ND & {$[97,107]$} \\
\hline $\mathrm{HalC} 8$ & $\begin{array}{l}\text { Natrinema } \quad \text { sp. } \\
\text { AS7092 }\end{array}$ & 7.4 & $\begin{array}{l}\text { Chaidan Salt } \\
\text { Lake in Qinghai } \\
\text { province, China }\end{array}$ & & ND & {$[104,108]$} \\
\hline HalR1 & $\begin{array}{l}\text { Hbt. salinarum } \\
\text { GN101 }\end{array}$ & 3.8 & $\begin{array}{l}\text { Guerrero Negro, } \\
\text { Mexico }\end{array}$ & $\begin{array}{l}\text { Members of the Ha- } \\
\text { lobacteriales, } \\
\text { Strains of Sulfolobus } \\
\text { sp., } \\
\text { Methanosarcina ther- } \\
\text { mophile }\end{array}$ & ND & {$[29,92]$} \\
\hline $\begin{array}{l}\text { Sulfolo- } \\
\text { bicins }\end{array}$ & $\begin{array}{l}\text { Sulfolobus } \\
\text { Islandicus HEN2/2 }\end{array}$ & $\begin{array}{l}33.9 \text { pro- } \\
\text { protein), } \\
3.6 \quad \text { (ma- } \\
\text { ture) }\end{array}$ & $\begin{array}{l}\text { Solfataric fields, } \\
\text { Iceland }\end{array}$ & $\begin{array}{l}\text { Strains of Sulfolobus } \\
\text { sp. }\end{array}$ & ND & [109] \\
\hline
\end{tabular}

Note: ND: Note Detected or Not Reported.

Roscetto et al. [110] reported that VLL-28 damages the cell wall of Candida albicans and C. parapsilosis by binding to their cell surface. Kumar and Tiwari [111] purified halocin HA1 from Haloferax larsenii HA1 and HA3 from H. larsenii HA3; both were halocidal against $H$. larsenii HA10, instigating cellular distortion, releasing cell contents, and finally causing cell death. Because of these properties, it can be used for the preservation of leather hides and salted foods in the leather and food industries. Ghanmi et al. [107] isolated Halobacterium salinarum ETD5, H. salinarum ETD8, and Haloterrigena thermotolerans SS1R12 of the order Halobacteriales and reported that their antimicrobial activity is due to the production of a halocin, HalS8, a hydrophobic peptide. Quadri et al. [112] isolated 
archeal strain Natrinema gari, the common producer of antimicrobial compounds, which after partial purification and characterization resembles the microhalocin HalC8. Besse et al. [108] confirmed that Natrinema sp. synthesizes Halocin C8, a 7.4 kDa peptide involving the genes halC8.

Although many studies characterized the synthesis of halocins however the research concerning their structure and mode of action is still far behind compared to the antibiotics produced by other domains. Nowadays, when archaea gain more attention, it becomes necessary to explore their metabolites' biosynthesis, including haloarcheocins and sulfolobicins, using the latest available technology and interdisciplinarity.

\section{Fungi}

In 1929, Alexander Fleming discovered that mold juice 'Penicillin' from Penicillium notatum fungus with an antibacterial activity [113]. Afterwards, several researchers started to find out for a better strain to attained higher yield in easier growth conditions. After the extensive research Penicillium chrysogenum strains considered for commercial production of Penicillium [114]. Revilla reported in 1986 that the formation of the intermediate isopenicillin $\mathrm{N}$ in the course of penicillin $\mathrm{G}$ production in P. chrysogenum cultures [115], while thereafter the formation of isopenicillin $\mathrm{N} /$ penicillin $\mathrm{N}$ and its late transformation to cephalosporin C in Acremonium chrysogenum [116]. Cephalosporins, a known antimicrobial agent were purified from a marine fungus, Cephalosporium acremonium [117]. Recently, Li et al [118] reported that pneumocandins, a lipohexapeptides of the echinocandin family, were produced by wild-type fungi Glarea lozoyensis and Pezicula (Cryptosporiopsis) species. Pneumocandins non-competitively bind to a catalytic unit of $\beta$-1,3-glucan synthase resulting in osmotic uncertainty and cell lysis.

\subsection{Endophytic fungi}

Huang et al. [119] discovered ten membered lactones from endophytic fungus Phomopsis sp. YM 311483, with antifungal activity against Aspergillus niger, Fusarium, and Botrytis cinere. Endophytic Fusarium sp. from Selaginella pollescens collected from the Guanacaste conservation area of Costa Rica inhibit Candida albicans [120]. The number of antimicrobial compounds was reported from the endophytic fungi, some of which are listed in Table 5.

Table 5. Antimicrobial compounds extracted from endophytic fungi.

\begin{tabular}{|c|c|c|c|c|c|}
\hline Compound & Chemical structure & Producer & Active against & Host & Reference \\
\hline $\begin{array}{l}\text { e 1, 4-naph- } \\
\text { thoquinone } \\
\text { derivatives }\end{array}$ & - & $\begin{array}{l}\text { Talaromyces sp. } \\
\text { SK-S009 }\end{array}$ & Pseudomonas sp. & Kandelia obovata & {$[121]$} \\
\hline Clavatol & & $\begin{array}{l}\text { Aspergillus clava- } \\
\text { tonanicus, Aspergil- } \\
\text { lus ele- } \\
\text { gans KUFA0015 }\end{array}$ & $\begin{array}{l}\text { Botrytiscinerea, Didymella bryo- } \\
\text { niae, Fusarium oxysporum } f \text {. } \\
\text { sp. cucumerinum, Rhizoctonia } \\
\text { solani, and Pythium ultimum }\end{array}$ & $\begin{array}{l}\text { Taxus mairei, } \\
\text { Monanchora un- } \\
\text { guiculate (Ma- } \\
\text { rine sponge) }\end{array}$ & [122] \\
\hline Lactones & & $\begin{array}{l}\text { Phomopsis sp. YM } \\
311483\end{array}$ & $\begin{array}{l}\text { A. niger, Botrytis cinere, and } \\
\text { Fusarium }\end{array}$ & $\begin{array}{l}\text { Azadirachta in- } \\
\text { dica }\end{array}$ & [123] \\
\hline Jesterone & & Pestalotiopsis jesteri & $\begin{array}{l}\text { Pythium ultimum, Phytophthora } \\
\text { citrophthora, Rhizoctonia solani } \\
\text { and Sclerotinia sclerotiorum }\end{array}$ & Fragraea bodenii & {$[124]$} \\
\hline $\begin{array}{l}\text { Peniciada- } \\
\text { metizine A }\end{array}$ & & $\begin{array}{l}\text { Penicillium } \\
\text { adametzioides AS- } \\
53 \text {, Penicillium jan- } \\
\text { thinellum strain } \\
\text { HDN13-309 }\end{array}$ & Alternaria brassica & $\begin{array}{l}\text { Sponge collected } \\
\text { at the Hainan Is- } \\
\text { land of China, } \\
\text { roots of Sonnera- } \\
\text { tia caseolaris }\end{array}$ & [125] \\
\hline
\end{tabular}




\subsection{Marine-derived fungi}

Meng et al. [126] in 2015 discovered pyranonigrin F from fungus Penicillium brocae MA-231 allied with the Avicennia marina, a marine mangrove plant. Pyranonigrin F inhibits S. aureus (Gram-positive), Vibrio harveyi, and Vibrio parahemolyticus (Gram-negative bacteria), with considerably lower MIC values as compared to the positive control (chloromycetin). Likewise, it is active against plant fungal pathogens Alternaria brassicae and Colletotrichum gloeosprioides, with improved MIC values compared to the positive control (bleomycin). Wu et al. [127] discovered Lindgomycin from Lindgomyces strains LF327 and KF970, reported from a sponge in the Baltic Sea, Germany, and Antarctica, respectively. Lindgomycin displayed antimicrobial activity against S. aureus, S. epidermidis, and methicillin-resistant S. epidermidis (MRSE). However, the inhibiting potential was two times lesser as compared to the positive control chloramphenicol. It also constrains plant pathogenic bacterium Xanthomonas campestris. There is a never-ending list of antimicrobial compounds from marine fungi; a few of them are listed in Table 6, mentioning their host, producer species, and bioactivity.

Table 6. Antimicrobial compounds extracted from marine fungi.

\begin{tabular}{|c|c|c|c|c|c|}
\hline Compounds & Structure & Producer & Active against & Environment source & Reference \\
\hline Penicisteroid A & & $\begin{array}{l}\text { Penicillium } \\
\text { chrysogenum } \\
\text { QEN-24S }\end{array}$ & $\begin{array}{l}\text { Aspergillus niger } \\
\text { and Alternaria } \\
\text { brassicae }\end{array}$ & $\begin{array}{l}\text { Marine algae associ- } \\
\text { ated Penicillium sp. }\end{array}$ & [128] \\
\hline Arisugacin $\mathrm{K}$ & & P. echinulatum & E. coli & $\begin{array}{l}\text { Marine alga Chondrus } \\
\text { ocellatus. }\end{array}$ & [129] \\
\hline $\begin{array}{l}\text { Methyl (Z)-3-(3, 4- } \\
\text { dihydroxy- } \\
\text { phenyl)-2- } \\
\text { Formamidoacry- } \\
\text { late }\end{array}$ & & $\begin{array}{l}\text { P. oxalicum } \\
\text { EN- } \\
290\end{array}$ & S. aureus & $\begin{array}{l}\text { Marine algae associ- } \\
\text { ated Penicillium }\end{array}$ & [130] \\
\hline $\begin{array}{l}\text { Chermesins A and } \\
\text { B }\end{array}$ & & $\begin{array}{l}\text { P. chermesinum } \\
\text { EN-480, }\end{array}$ & $\begin{array}{l}\text { C. albicans, } \\
\text { E. coli, M. luteus, } \\
\text { and V. alginolyticus }\end{array}$ & $\begin{array}{l}\text { Marine algae associ- } \\
\text { ated Penicillium }\end{array}$ & [131] \\
\hline $\begin{array}{l}\text { Comazaphilones } \\
\text { C (C-E) }\end{array}$ & & $\begin{array}{l}\text { P. commune } \\
\text { QSD-17 }\end{array}$ & Antibacterial & $\begin{array}{l}\text { Penicillium sp. from } \\
\text { marine sediments }\end{array}$ & [132] \\
\hline Penicibilaenes A & & $\begin{array}{l}\text { P. bilaiae MA- } \\
267\end{array}$ & $\begin{array}{l}\text { Colletotrichum gloe- } \\
\text { osporioides }\end{array}$ & $\begin{array}{l}\text { Rhizospheric soil of } \\
\text { Lumnitzera racemosa }\end{array}$ & [133] \\
\hline
\end{tabular}


Xylarinonericin D and $\mathrm{E}$

Terretonin G

Schevalone E

Asperitaconic acids A-C

Ochramide B

Spiculisporic acids $F$ and $G$

Aspergicin

Asperamide

Flavusides A and B

Isorhodoptilometrin1-methyl ether
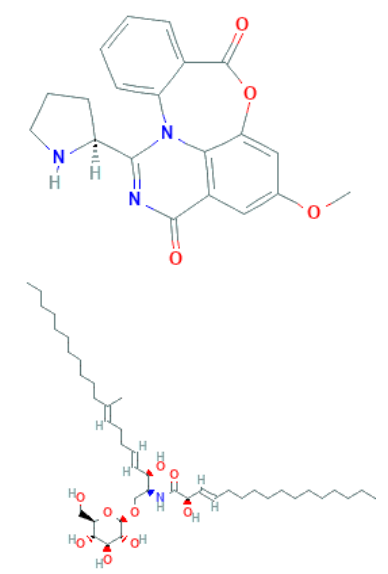
aureus

Aspergillus sp. S. aureus, S. epider-
A. niger $\mathrm{EN}-13$

C. albicans

S. aureus and MRSA

B. subtilis, B. cereus and

S. aureus

Alternaria brassicae, E. coli, Edwardsiella tarda, Physalospora piricola, and $S$.

Beibu Gulf nearby

Guangxi

[129]

Sponge Rhabdermia sp. from the coral reef of the Similan Island Sponges-associated Aspergillus sp. FSY-01 and midis, B. subtilis, B. dysenteriae, $B$. proteus and E. coli,

Mangrove Avicennia marina in Guangdong.

Marine algae associated Aspergillus sp.

[140] ated Aspergillus sp.

Marine algae associ-

Paecilomyces lilacinus EN-531 and $A$. terreus EN-539 ated Aspergillus sp.

Marine algae associated Aspergillus sp. 
Speradine A

Versiperol A

\section{Ergosterdiacids A
and B}

Heptapeptide

RHM1

Trichoderins A

Botryorhodines I and $\mathrm{J}$

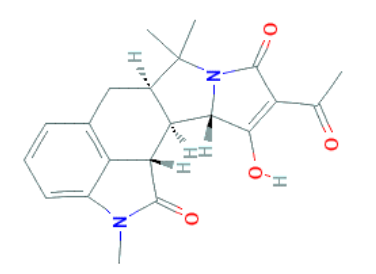

A. tamarii

M143

Mycrococcus luteus

driftwood in Okinawa

[144]

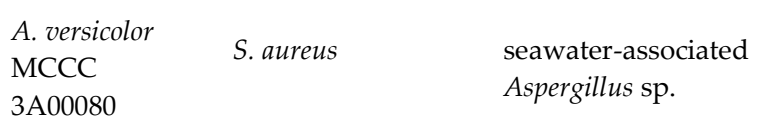

[145]
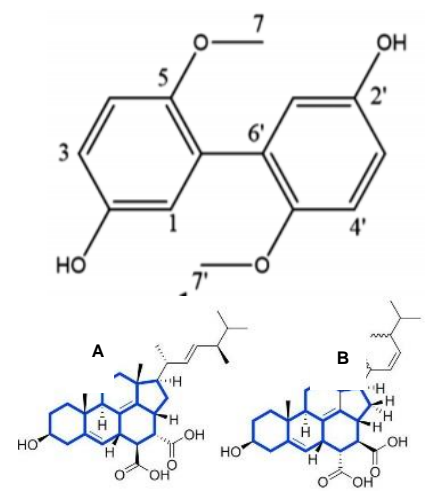

Aspergillus sp.

M. tuberculosis

Marine sediments associated Aspergillus sp.

[146]

$\begin{array}{lll}\begin{array}{l}\text { Acremonium } \\ \text { sp. HM1 }\end{array} & \text { S. epidermidis } & \begin{array}{l}\text { Marine sponges-asso- } \\ \text { ciated fungi }\end{array} \\ \begin{array}{l}\text { Trichoderma } \\ \text { sp. 05FI48 }\end{array} & \text { M. smegmatis } & \begin{array}{l}\text { Marine sponges-asso- } \\ \text { ciated fungi }\end{array} \\ \begin{array}{l}\text { Setosphaeria sp. } \\ \text { SCSIO }\end{array} & \begin{array}{l}\text { Colletotrichum } \\ \text { asianum }\end{array} & \begin{array}{l}\text { Marine sponge Cally- } \\ \text { spongia sp. }\end{array}\end{array}$

Peniciadametizine A and Peniciadametizine B derivative of thiolated diketopiperazine was isolated from a sponges-associated Penicillium sp. viz. Penicillium adametzioides AS-53 and Penicillium sp. LS54 respectively. Both derivative inhibits Alternaria brassicae (pathogenic fungus) with a MIC of $4.0 \mu \mathrm{g} / \mathrm{mL}$ and $32.0 \mu \mathrm{g} / \mathrm{mL}$ respectively [131]. Communol A, G, and F extracted from P. commune 518 displayed antibacterial activities against E. coli with MIC values of 4.1, 23.8, and $6.4 \mu \mathrm{M}$, respectively, and also against E. aerogenes [129]. Pyrrospirones were produced by marine-derived fungus Penicillium sp. ZZ380, isolated from Pachygrapsus crassipes which is a wild crab found on the seaside rocks of Putuo Mountain (Zhoushan, China). Pyrrospirones C-F, H, and I inhibit MRSA and E. coli having MIC values of $2.0-19.0 \mu \mathrm{g} / \mathrm{mL}$ [149]. Song et al. [150], following the previous lead, separated penicipyrrodiether A from a cultured marine fungal strain Penicillium sp. ZZ380 inhibits E. coli and S. aureus with MIC of 34.0 and $5.0 \mu \mathrm{g} / \mathrm{mL}$, respectively. These laboratory studies need to be directed toward enlightening the efficiency and effectiveness of isolated compounds that could benefit society in the long-run.

\subsection{Mushroom}

Mushrooms are colonizing fungi belonging to division Eumycota and subdivision Basidiomycetes, characterized by the formation of basidiospores. Most of these macrofungi are edible, with culinary, nutritional, and medicinal characteristics, but many of them are not palatable or poisonous [151]. Besides the nutritional and culinary properties, their antimicrobial activities attracted people seeking natural solutions to cope with the urgent requirement for food safety. Mushrooms have been publicly consumed for thousands of years due to their medicinal and nutritional properties. Secondary metabolites and extracts from mushrooms have recently attained considerable attention due to their anti-cancer, antioxidant, anti-inflammatory, antimicrobial, antidiabetic, and immunomodulatory activities. Approximately 1069 mushroom species have been consumed by people [152]. Till today, numerous antimicrobial peptides have been acknowledged from mushrooms. Plectasin (endogenous peptide antibiotics), an antibacterial peptide, was extracted from Pseudoplectania nigrella. Mygind et al. [153] demonstrated the potent activity 
of recombinant plectasin against some Gram-positive Streptococcus pneumoniae. Wong et al. [154] described an antifungal peptide, cordymin isolated from medicinal mushroom Cordyceps militaris, which repressed mycelial growth of Bipolaris maydis, Mycosphaerella arachidicola, Candida albicans, and Rhizoctonia solani with IC 50 values of $50 \mu \mathrm{M}, 10 \mu \mathrm{M}, 0.75$ $\mathrm{mM}$, and $80 \mu \mathrm{M}$ respectively. They also reported the remarkable $\mathrm{pH}$ stability ( $\mathrm{pH} 6-13)$, thermostability $\left(100{ }^{\circ} \mathrm{C}\right)$, and metal ion stability $\left(10 \mathrm{mM} \mathrm{Mg}{ }^{2+}\right.$ and $\left.10 \mathrm{mM} \mathrm{Zn}^{2+}\right)$ of cordymin. An investigation by Gebreyohannes et al. [155] revealed that chloroform, ethanol, and hot water extract of Auricularia and Termitomyces sp. promisingly inhibited E. coli, K. pneumoniae, C. parapsilosis, and S. aureus. Poompouang and Suksomtip, [156] isolated an antifungal compound of $17 \mathrm{kDa}$ from fruiting bodies of edible mushroom Lentinus squarrosulus, inhibiting Trichophyton mentagrophytes and T. rubrum, a human fungal pathogen. More recently, Irshad et al. [157] comprehensively reviewed the synthesis and action mechanism of polysaccharides silver nanoparticles (NPs) from Pleurotus mushroom. They characterized the NPs through ultraviolet-visible (UV-Vis), Fourier transformation infrared spectroscopy (FT-IR), scanning electron microscopy (SEM), energy dispersive spectroscopy (EDS), transmission electron microscopy (TEM), etc. and disclosed their promising antimicrobial efficiency. However, further studies are required to fortify and test these extracts and NPs against human and plant pathogenic microbes coupled with the purification and characterization of the compounds from mushroom.

Hamamoto et al. [158] screened the volatile compound, 3,4-dichloro-4-methoxy benzaldehyde (DCMB) from mycelia of Porostereum spadiceum. It remarkably inhibited the plant-pathogenic bacteria (Clavibacter michiganensis and Ralstonia solanacearum) and inhibit the conidial germination of plant-pathogenic fungi (Alternaria brassicicola and Colletotrichum orbiculare). However, further studies are essential to investigate its effects on plant-pathogens in vivo. Subrata et al. [159] reported that edible wild mushrooms' methanolic extracts exhibited different levels of antimicrobial activities. A recent work by Sevindi [160] analysed the phenolic content of the wild edible mushroom Melanoleuca melaleuca (Pers.) Murrill had antimicrobial activities inhibiting Gram-negative E. coli, Pseudomonas aeruginosa, and Acinetobacter baumannii.

\section{Yeast}

Yeasts mainly occur in milk, meat, food, and products such as fruit, yogurt, jams, sausage, and cheeses. Generally, antimicrobial compounds produced from yeasts inhibit the evolution/growth of pathogenic organisms (bacteria or molds) in food products. Some classes of yeasts secrete toxins, thereby naming them killer yeasts. Killer yeasts naturally occur in rotten vegetables and fruits and constrain the growth of other yeast strains and also inhibit microbial growth [161]. Saccharomyces cerevisiae (Baker's yeast), unicellular yeast, is the most widely studied microorganisms involved in many biotechnological practices because of its good fermentation capacity [162]. The inhibitory mechanism of $S$. cerevisiae killer strains was discovered in 1963 by Bevan and co-worker's, and the phenomenon is related to the secretion of a protein toxin, $k 1$, and $k 28$ from the host that kills sensitive target pathogenic cells in a receptor-mediated approach without direct cell-to-cell contact [163]. Other genera producing killer toxins include Cryptococcus, Candida, Kluyveromyces, Williopsis, Pichia, Debaromyces, and Zygosaccharomyces [164]. The anti-bacterial capability of $S$. cerevisiae is attributed to:

a) Secretion of inhibitory proteins

b) Production of extracellular protease

c) Stimulation of immunoglobulin A

d) Procurement and eradication of secreted toxins

e) Killer toxins, sulfur dioxide, etc.

Sequential re-pitching of Saccharomyces biomass is a common process during brewing. Therefore, yeast is reused many times before its final dumping [165]. Hence, yeast develops an adaptive response against oxidative stress like that of human cells, leading to the accumulation of vitamins (B6 and B12) and minerals (enzyme co-factors including 
zinc, manganese, and copper) in the yeast cell. Phenolic compounds are also adsorbed by Saccharomyces from the exterior medium, which increases the phenolic content and antioxidant activity within yeast cells [166]. Efficient means are required to disrupt yeast cell walls and separate the products of interest, which are further used for food applications. However, increasing consumers' fears regarding the toxicity of killer yeast strains present in food, and milk products, constituting a direct risk to public health.

\section{Microalgae}

The antimicrobial activity of microalgae is due to the presence of phytochemicals, including indoles, acetogenins, terpenes, fatty acids, phenols, and volatile halogenated hydrocarbons (Table 7) [167]. Moreno et al. [168] reported that Chaetoceros muelleri extracts' antimicrobial activity is due to their lipid configuration, whereas Dunaliella salina is attributed to the presence of $\beta$-cyclocitral, $\alpha$ and $\beta$-ionone, phytol, and neophytadiene. In natural environmental conditions, microalgal cells release fatty acids against predators and pathogenic bacteria. It is elucidated that these fatty acids act on bacterial cell membranes causing cell seepage, a decline in nutrient intake, and reduced cellular respiration, ultimately resulting in cell death [169].

Table 7. Selected antimicrobial extracts from microalgae.

\begin{tabular}{|c|c|c|c|}
\hline Microalga & Target microorganism & Active extract & References \\
\hline Scenedesmus quadricauda & S. aureus and $P$. aeruginosa & Methanolic extract & [170] \\
\hline Tetraselmis sp. & E. coli, $P$. aeruginosa, and $S$. aureus & Ethanolic extract & {$[171]$} \\
\hline Phaeodactylum tricornutum & $\begin{array}{l}\text { Listonella anguillarum, Lactococcus } \\
\text { garvieae,Vibrio spp. and MRSA }\end{array}$ & Eicosapentaenoic acid & [169] \\
\hline C. vulgaris & Steinernema feltiae & Hydrophilic extracts & {$[172]$} \\
\hline Skeletonema costatum & Listeria monocytogenes & Extra-metabolites & \\
\hline S. costatum & $\begin{array}{l}\text { Vibrio spp., Pseudomonas sp. and Listeria } \\
\text { monocytogenes }\end{array}$ & $\begin{array}{l}\text { Unsaturated, saturated } \\
\text { long-chain fatty acids }\end{array}$ & [173] \\
\hline Haematococcus pluvialis & E. coli, S. aureus, Candida albicans & $\begin{array}{l}\text { Short-chain fatty acids } \\
\text { (butanoic acid and } \\
\text { methyl lactate), Astaxan- } \\
\text { thin }\end{array}$ & {$[174]$} \\
\hline Amphidinium sp. & A. niger, Trichomonas foetus & Karatungiols & [175] \\
\hline Chlamydomonas reinhardtii & $\begin{array}{l}\text { A. niger, A. fumigatus, C. albicans, S. aureus } \\
\text { and E. coli }\end{array}$ & Methanolic extracts & [176] \\
\hline
\end{tabular}

Chlorellin, the first antibacterial compound from a microalga Chlorella is composed of a mixture of fatty acid was isolated by Pratt et al. [177] reported to inhibit the activity of both Gram-positive and Gram-negative bacteria. Arthrospira platensis, commercially known as Spirulina had MIC of $0.20 \%$ for L. innocua and P. fluorescens and $0.25 \%$ for Serratia, whereas minimal bactericidal concentration (MBC) value was $0.30 \%$ for all these species [178]. HPTLC screening and GC-MS analyses were done to detect and screen the macroalgae's antimicrobial compounds. Peptides namely AQ-1756, AQ-1757, and AQ1766 identified from Tetraselmis suecica exhibited an antibacterial activity resulting in decreasing cell viability (human embryonic kidney cells) (HEK293) up to 75\% after 24 h of 
treatment. AQ-1766 was more active against Gram-positive than Gram-negative bacteria, with MBC values between 40 and $50 \mu \mathrm{M}$ [179]. Mendiola et al. [180] demonstrated that lipid fractions obtained from Chaetoceros muelleri by the supercritical $\mathrm{CO}_{2}$ method have antibacterial activity against Staphyloccocus aureus and E. coli. In contrast, extraction via classic methods using hexane, dichloromethane, and methanol solvent did not possess any activity against $E$. coli. However, these studies were unable to elaborate on these bioactive compounds' antibacterial activity's exact mode of action.

Axenic microalgae co-culture can produce compounds with potent activity against pathogenic bacteria. Kokou et al. [181] reported that axenic cultures of Tetraselmis chui, Chlorella minutissima, Isochrysis sp. and Nannochloropsis sp. inhibit Vibrio harveyi . The potent activity of microalgal compounds against microbes requires further development in the search for drugs and food preservatives. Therefore, the exploitation in medicine deserves to be further investigated.

\section{Discussion and Future prospect}

One of the major challenges healthcare services face worldwide is the excessive use of antibiotics as medicine and in food production leading to microbiome disruption. With the burst of antimicrobial resistance strains, there is a continuous decline in the antimicrobial drug pipeline, and it has become mandatory to discover and develop new agents/metabolites to tackle antibiotic resistance. The microbial metabolites were used as antibiotics with the discovery of penicillin and are easy to isolate, culture, and engineered compared to plants. After discovering penicillin, many drug discoveries from microbial sources had been reported, and the advancement of techniques such as genetic engineering during the 1970s, which later on opened the door to the ignored source, i.e., microbial metabolites [182].

Microbial products are vital constituents of new drug molecules, and ample research is being carried out to search for novel antimicrobial agents from biological sources that include bacteria, actinomycetes, fungi, yeast, etc. LAB producing bacteriocins, antimicrobial ribosomal peptides, is a promising advancement for the food and feed industry by extending their shelf life and safeguarding consumers' health. Actinomycetes, particularly Streptomyces, exhibited effective antagonistic activity and played a significant role in drug discovery and development. The bioactive compounds obtained so far from actinomycetes include streptomycin, antimycin, vinaceuline, bafilomycin, diastaphenazine, etc. However, not all of them have achieved commercial success. This might be due to the low potency of drugs, their pharmacological properties, related safety issues, or the rapid advent of resistant strains.

In the ongoing search for novel antibiotics, archaeocins have generally been overlooked. Halocins are extensively reviewed and halocin $\mathrm{H} 6$ has been revealed to inhibit the $\mathrm{Na}+\mathrm{H}+$ antiporter causing cell lysis and death of pathogens. Further studies on purifications and characterizations to the archaeocins and sulfolobicins are in progress, resulting in the economical production of bioactive compounds for pharmaceutical applications. It becomes desirable to expand our understanding of the effectiveness and use of other naturally occurring ribosomally-synthesized peptide antimicrobials to understand their implantation and survival strategies and quantitatively estimate their efficacy for future applications pharmaceutical and health care sectors.

Many achievements have been made regarding fungal antibiotics starting from penicillin. Fungi synthesized small quantities of bioactive compounds in response to explicit environmental conditions, which cannot be reproduced easily in the laboratory. Therefore, effective methods of strain improvement are required to increase the ability of a fungus to produce bioactive metabolites in large amounts consistently. Also, to develop novel antimicrobial drugs from these fungal metabolites, commercial-scale synthesis must be accomplished, potentially through strain improvement, optimizing growth conditions, and incorporating techniques, such as metabolomics, genomics, and pathway engineering. 
Endophytic and marine-derived fungi offer a suitable substitute against toxic, ineffective, and expensive antimicrobial drugs because they act as a warehouse filled with novel bioactive compounds with never-ending potentials for biological properties. Apart from other fungal species, mushrooms are continued to be consumed in their natural forms since time immemorial.

Antimicrobials, isolated from mushrooms, are important as potential substitutes to synthetic drugs and preservatives, whose protection and influence on the health of humans, animals, and food are still uncertain. This review demonstrates that edible mushrooms are a potent source of countless bioactive substances with antimicrobial activity. Hence, they must not be considered only as a culinary delicacy but also taken as therapeutic agents. However, we are still required to develop methods for isolation, purification, identification, and characterization of antimicrobial compounds to develop antibiotics.

Microalgae are a promising source of high-value products, and large-scale screening programs have been conducted to discover the antimicrobial potential of microalgal extracts against pathogenic and foodborne organisms. However, major antibacterial and antifungal activity reports were predominantly from the chlorella sp. and Chlamydomonas sp. Still, many hurdles exist in developing the marine product, including resource supply issues, large-scale production, production cost, determination of the efficacy target [183]. These obstacles must be bypassed by optimizing mass culturing conditions, utilizing biotechnological techniques, etc. Along with these measures, extensive clinical trials will be needed to determine the in-vivo fortune of antimicrobials from microbial extracts on mammalian cells. A consolidated bio-refinery approach must be accepted to expand the utility of microalgae biomass [167]. Systematic research should be carried to evaluate the microalgae potential as a promising biotechnology tool.

Although killer yeasts strain secret toxins, many yeasts have antimicrobial activities inhibiting other yeast strains, molds, and bacteria. Regardless of this, preliminary research has been conducted on the bioactive compounds from S. cerevisiae; the widely studied yeast has been involved in many biotechnological processes because of its good fermentation capacity, probiotics, and health benefits. Therefore, developing and using robust screening and high-throughput methods will be essential to study yeast antimicrobial activity, thereby increasing the chances of discovering and identifying novel antibiotic molecules. To achieve this goal, the experimental design must include all possible variables, including recovering both intra- and extracellular extracts produced by microbes under variable growth conditions, utilizing potential inducers of antimicrobial activity, and testing these compounds against a more significant number of targets.

The detailed functional and structural knowledge would explain the mode of action and performance at cellular and molecular levels.

\section{Conclusions}

In the present review, it could be concluded that the promising novelty of microorganisms brought them under the focus of intensive research. Microbes' applications in human foods, animal feeds, agriculture, and increased market demand are motivating to continue the research and development of novel antibiotics and preservatives. Furthermore, the molecular docking and structural analysis approach can better design pathogenspecific antimicrobial agents that exhibit lesser toxicity, higher selectivity, and biodegradability. Therefore, exploiting microbial biodiversity and biotechnological potential to determine new pipelines for bioactive compounds discovery is approached to treat lifethreatening diseases and safeguard human health.

Author Contributions: Acquisition of data, analysis and original draft and table preparation, A.R.; Formal analysis, reviewing and figure preparation, K. C. S. and S.V.; review and editing, F.B., S.M., S.K.B., N.S. and C.F. All authors have read and agreed to the published version of the manuscript.

Funding: This research received no external funding. 


\begin{abstract}
Acknowledgments: A.R. acknowledges the Indian Council of Medical Research (ICMR), New Delhi, India for the SRF. K.C.S. gratefully acknowledges the Council of Scientific and Industrial Research (CSIR), New Delhi, India, for the financial support towards Ph.D. Both A.R. and K.C.S. Acknowledges the Central University of Punjab, for administrative and technical support. The author also would like to acknowledge the KU Research Professor Program of Konkuk University, Seoul, South Korea. Diagrams were created with BioRender.com and molecular structures were retrieved from PubChem (https://pubchem.ncbi.nlm.nih.gov/).
\end{abstract}

Conflicts of Interest: The authors declare no conflict of interest.

\title{
References
}

1. Santajit, S.; Indrawattana, N., Mechanisms of antimicrobial resistance in ESKAPE pathogens. BioMed research international 2016, 2016.

2. Centers for Disease Control and Prevention 2019. Antibiotic resistance threats in the United States. https://www.cdc.gov/drugresistance/pdf/threats-report/2019-ar-threats-report-508.pd (accessed 29 January 2021).

3. Pendleton, J. N.; Gorman, S. P.; Gilmore, B. F., Clinical relevance of the ESKAPE pathogens. Expert review of antiinfective therapy 2013, 11 (3), 297-308.

4. Mulani, M. S.; Kamble, E. E.; Kumkar, S. N.; Tawre, M. S.; Pardesi, K. R., Emerging Strategies to Combat ESKAPE Pathogens in the Era of Antimicrobial Resistance: A Review. Frontiers in Microbiology 2019, 10 (539).

5. Van Boeckel, T. P.; Brower, C.; Gilbert, M.; Grenfell, B. T.; Levin, S. A.; Robinson, T. P.; Teillant, A.; Laxminarayan, R., Global trends in antimicrobial use in food animals. Proceedings of the National Academy of Sciences 2015, 112 (18), 5649-5654.

6. Andrei, S.; Valeanu, L.; Chirvasuta, R.; Stefan, M.-G., New FDA approved antibacterial drugs: 2015-2017. Discoveries (Craiova) 2018, 6 (1), e81-e81.

7. FDA Drugs@FDA: FDA-Approved Drugs. https://www.fda.gov/drugs/new-drugs-fda-cders-new-molecularentities-and-new-therapeutic-biological-products/novel-drug-approvals-2020 (accessed 12 March, 2021).

8. Rani, A.; Saini, K. C.; Bast, F.; Mehariya, S.; Bhatia, S. K.; Lavecchia, R.; Zuorro, A., Microorganisms: A Potential Source of Bioactive Molecules for Antioxidant Applications. Molecules 2021, 26 (4), 1142.

9. Newman, D. J.; Cragg, G. M., Natural products as sources of new drugs over the 30 years from 1981 to 2010. Journal of natural products 2012, 75 (3), 311-335.

10. Mazzoli, R.; Riedel, K.; Pessione, E., Editorial: Bioactive Compounds from Microbes. Frontiers in microbiology 2017, 8, 392-392.

11. Vestby, L. K.; Grønseth, T.; Simm, R.; Nesse, L. L., Bacterial Biofilm and its Role in the Pathogenesis of Disease. Antibiotics (Basel) 2020, 9 (2), 59.

12. Ting, D. S. J.; Ho, C. S.; Deshmukh, R.; Said, D. G.; Dua, H. S., Infectious keratitis: an update on epidemiology, causative microorganisms, risk factors, and antimicrobial resistance. Eye 2021.

13. Sumi, C. D.; Yang, B. W.; Yeo, I.-C.; Hahm, Y. T., Antimicrobial peptides of the genus Bacillus: a new era for antibiotics. Canadian journal of microbiology 2015, 61 (2), 93-103.

14. Zhao, X.; Kuipers, O. P., Identification and classification of known and putative antimicrobial compounds produced by a wide variety of Bacillales species. BMC Genomics 2016, 17 (1), 882.

15. Caulier, S.; Nannan, C.; Gillis, A.; Licciardi, F.; Bragard, C.; Mahillon, J., Overview of the antimicrobial compounds produced by members of the Bacillus subtilis group. Frontiers in microbiology 2019, 10, 302.

16. Praptiwi; Fathoni, A.; Putri, A. L.; Wulansari, D.; Agusta, A. In Assessment of actinomycetes isolated from soils on Simeuleu Island as antibacterial and antioxidant, AIP Conference Proceedings, AIP Publishing LLC: 2019; p 080011.

17. Register, F., Nisin preparation: affirmation of GRAS status as a direct human food ingredient. Federal Register $1988,53,11247-11251$. 
18. Lozo, J.; Vukasinovic, M.; Strahinic, I.; Topisirovic, L., Characterization and antimicrobial activity of bacteriocin 217 produced by natural isolate Lactobacillus paracasei subsp. paracasei BGBUK2-16. Journal of food protection 2004 , 67 (12), 2727-2734.

19. Drissi, F.; Buffet, S.; Raoult, D.; Merhej, V., Common occurrence of antibacterial agents in human intestinal microbiota. Frontiers in Microbiology 2015, 6 (441).

20. Leite, J. A.; Tulini, F. L.; Reis-Teixeira, F. B. d.; Rabinovitch, L.; Chaves, J. Q.; Rosa, N. G.; Cabral, H.; De Martinis, E. C. P., Bacteriocin-like inhibitory substances (BLIS) produced by Bacillus cereus: Preliminary characterization and application of partially purified extract containing BLIS for inhibiting Listeria monocytogenes in pineapple pulp. LWT Food Science and Technology 2016, 72, 261-266.

21. Choeisoongnern, T., Sivamaruthi, B. S., Sirilun S., ; Sartjin P., Y. C., Hanitra R., Thomas H. and Chaiyavat C., Screening and identification of bacteriocin-like inhibitory substances producing lactic acid bacteria from fermented products. Food Science and Technology 2019, (AHEAD).

22. Gradisteanu Pircalabioru, G.; Popa, L. I.; Marutescu, L.; Gheorghe, I.; Popa, M.; Czobor Barbu, I.; Cristescu, R.; Chifiriuc, M.-C., Bacteriocins in the Era of Antibiotic Resistance: Rising to the Challenge. Pharmaceutics 2021, 13 (2), 196.

23. Jawan, R.; Abbasiliasi, S.; Mustafa, S.; Kapri, M. R.; Halim, M.; Ariff, A. B., In Vitro Evaluation of Potential Probiotic Strain Lactococcus lactis Gh1 and Its Bacteriocin-Like Inhibitory Substances for Potential Use in the Food Industry. Probiotics and Antimicrobial Proteins 2020.

24. Hyun, W. B.; Kang, H. S.; Lee, J. W.; Abraha, H. B.; Kim, K.-P., A newly-isolated Bacillus subtilis BSC35 produces bacteriocin-like inhibitory substance with high potential to control Clostridium perfringens in food. LWT 2021, 138, 110625.

25. Garsa, A. K.; Choudhury, P. K.; Puniya, A. K.; Dhewa, T.; Malik, R. K.; Tomar, S. K., Bovicins: the bacteriocins of streptococci and their potential in methane mitigation. Probiotics and antimicrobial proteins 2019, 11 (4), $1403-1413$.

26. Meade, E.; Slattery, M. A.; Garvey, M., Bacteriocins, potent antimicrobial peptides and the fight against multi drug resistant species: resistance is futile? Antibiotics 2020, 9 (1), 32.

27. Shand, R. F.; Leyva, K. J., Peptide and Protein Antibiotics from the Domain Archaea: Halocins and Sulfolobicins. In Bacteriocins: Ecology and Evolution, Riley, M. A.; Chavan, M. A., Eds. Springer Berlin Heidelberg: Berlin, Heidelberg, 2007; pp 93-109.

28. Ibrahim, O. O., Classification of antimicrobial peptides bacteriocins, and the nature of some bacteriocins with potential applications in food safety and bio-pharmaceuticals. EC Microbiol 2019, 15, 591-608.

29. O'connor, E.; Shand, R., Halocins and sulfolobicins: the emerging story of archaeal protein and peptide antibiotics. Journal of Industrial Microbiology and Biotechnology 2002, 28 (1), 23-31.

30. Garcia-Gutierrez, E.; Mayer, M. J.; Cotter, P. D.; Narbad, A., Gut microbiota as a source of novel antimicrobials. Gut Microbes 2019, 10 (1), 1-21.

31. Newstead, L. L.; Varjonen, K.; Nuttall, T.; Paterson, G. K., Staphylococcal-Produced Bacteriocins and Antimicrobial Peptides: Their Potential as Alternative Treatments for Staphylococcus aureus Infections. Antibiotics 2020, $9(2), 40$.

32. Negash, A. W.; Tsehai, B. A., Current Applications of Bacteriocin. International Journal of Microbiology 2020, 2020, 4374891.

33. Małaczewska, J.; Kaczorek-Łukowska, E., Nisin-A lantibiotic with immunomodulatory properties: A review. Peptides 2021, 137, 170479.

34. Yu, X.; Lu, N.; Wang, J.; Chen, Z.; Chen, C.; Mac Regenstein, J.; Zhou, P., Effect of N-terminal modification on the antimicrobial activity of nisin. Food Control 2020, 107227. 
35. Peng, X.; Zhu, L.; Wang, Z.; Zhan, X., Enhanced stability of the bactericidal activity of nisin through conjugation with gellan gum. International Journal of Biological Macromolecules 2020, 148, 525-532.

36. Heunis, T. D.; Smith, C.; Dicks, L. M., Evaluation of a nisin-eluting nanofiber scaffold to treat Staphylococcus aureus-induced skin infections in mice. Antimicrobial agents and chemotherapy 2013, 57 (8), 3928-3935.

37. Field, D.; Seisling, N.; Cotter, P. D.; Ross, R. P.; Hill, C., Synergistic Nisin-Polymyxin Combinations for the Control of Pseudomonas Biofilm Formation. Frontiers in Microbiology 2016, 7 (1713).

38. Alves, F. C. B.; Albano, M.; Andrade, B. F. M. T.; Chechi, J. L.; Pereira, A. F. M.; Furlanetto, A.; Rall, V. L. M.; Fernandes, A. A. H.; Dos Santos, L. D.; Barbosa, L. N., Comparative proteomics of methicillin-resistant Staphylococcus aureus subjected to synergistic effects of the lantibiotic nisin and oxacillin. Microbial Drug Resistance 2020, 26 (3), 179189.

39. El-Kazzaz, S. S.; Abou El-Khier, N. T., Effect of the lantibiotic nisin on inhibitory and bactericidal activities of antibiotics used against vancomycin-resistant enterococci. Journal of global antimicrobial resistance 2020, 22, $263-269$. 40. Webber, J. L.; Namivandi-Zangeneh, R.; Drozdek, S.; Wilk, K. A.; Boyer, C.; Wong, E. H. H.; Bradshaw-Hajek, B. H.; Krasowska, M.; Beattie, D. A., Incorporation and antimicrobial activity of nisin Z within carrageenan/chitosan multilayers. Scientific Reports 2021, 11 (1), 1690.

41. Shindo, K.; Takenaka, A.; Noguchi, T.; Hayakawa, Y.; Seto, H., Thiazostatin A and thiazostatin B, new antioxidants produced by Streptomyces tolurosus. The Journal of antibiotics 1989, 42 (10), 1526-1529.

42. Perez, R. H.; Perez, M. T. M.; Elegado, F. B., Bacteriocins from lactic acid bacteria: a review of biosynthesis, mode of action, fermentative production, uses, and prospects. International Journal of Philippine Science and Technology 2015, 8 (2), 61-67.

43. Wang, H.; Fewer, D. P.; Holm, L.; Rouhiainen, L.; Sivonen, K., Atlas of nonribosomal peptide and polyketide biosynthetic pathways reveals common occurrence of nonmodular enzymes. Proceedings of the National Academy of Sciences 2014, 111 (25), 9259-9264.

44. Aleti, G.; Sessitsch, A.; Brader, G., Genome mining: prediction of lipopeptides and polyketides from Bacillus and related Firmicutes. Computational and Structural Biotechnology Journal 2015, 13, 192-203.

45. Alvarez-Sieiro, P.; Montalbán-López, M.; Mu, D.; Kuipers, O. P., Bacteriocins of lactic acid bacteria: extending the family. Applied microbiology and biotechnology 2016, 100 (7), 2939-2951.

46. Baltz, R. H., Combinatorial biosynthesis of cyclic lipopeptide antibiotics: a model for synthetic biology to accelerate the evolution of secondary metabolite biosynthetic pathways. ACS synthetic biology 2014, 3 (10), 748-758.

47. Perez, K. J.; Viana, J. d. S.; Lopes, F. C.; Pereira, J. Q.; dos Santos, D. M.; Oliveira, J. S.; Velho, R. V.; Crispim, S. M.; Nicoli, J. R.; Brandelli, A.; Nardi, R. M. D., Bacillus spp. Isolated from Puba as a Source of Biosurfactants and Antimicrobial Lipopeptides. Frontiers in Microbiology 2017, 8 (61).

48. Kourmentza, K.; Gromada, X.; Michael, N.; Degraeve, C.; Vanier, G.; Ravallec, R.; Coutte, F.; Karatzas, K. A.; Jauregi, P., Antimicrobial Activity of Lipopeptide Biosurfactants Against Foodborne Pathogen and Food Spoilage Microorganisms and Their Cytotoxicity. Frontiers in Microbiology 2021, 11 (3398).

49. Isa, M. H. M.; Shannaq, M. A.-H. F.; Mohamed, N.; Hassan, A. R.; Al-Shorgani, N. K. N.; Hamid, A. A., Antibacterial activity of surfactin produced by Bacillus subtilis MSH1. Transactions on Science and Technology 2017, 4 (33), 402-407.

50. Calvo, H.; Mendiara, I.; Arias, E.; Blanco, D.; Venturini, M., The role of iturin A from B. amyloliquefaciens BUZ-14 in the inhibition of the most common postharvest fruit rots. Food microbiology 2019, 82, 62-69.

51. Sur, S.; Romo, T. D.; Grossfield, A., Selectivity and mechanism of fengycin, an antimicrobial lipopeptide, from molecular dynamics. The Journal of Physical Chemistry B 2018, 122 (8), 2219-2226. 
52. Meena, K.; Sharma, A.; Kanwar, S., Microbial lipopeptides and their medical applications. Ann Pharmacol Pharm. 2017; 2 (24) 2017, 1126.

53. Qi, G.; Zhu, F.; Du, P.; Yang, X.; Qiu, D.; Yu, Z.; Chen, J.; Zhao, X., Lipopeptide induces apoptosis in fungal cells by a mitochondria-dependent pathway. Peptides 2010, 31 (11), 1978-1986.

54. Inès, M.; Dhouha, G., Lipopeptide surfactants: production, recovery and pore forming capacity. Peptides 2015, 71, 100-112.

55. Straus, S. K.; Hancock, R. E., Mode of action of the new antibiotic for Gram-positive pathogens daptomycin: comparison with cationic antimicrobial peptides and lipopeptides. Biochimica et Biophysica Acta (BBA)-Biomembranes 2006, 1758 (9), 1215-1223.

56. Nasir, M. N.; Besson, F., Interactions of the antifungal mycosubtilin with ergosterol-containing interfacial monolayers. Biochimica et Biophysica Acta (BBA)-Biomembranes 2012, 1818 (5), 1302-1308.

57. Ma, Z.; Zhang, S.; Sun, K.; Hu, J., Identification and characterization of a cyclic lipopeptide iturin A from a marine-derived Bacillus velezensis 11-5 as a fungicidal agent to Magnaporthe oryzae in rice. Journal of Plant Diseases and Protection 2020, 127 (1), 15-24.

58. Malfanova, N.; Franzil, L.; Lugtenberg, B.; Chebotar, V.; Ongena, M., Cyclic lipopeptide profile of the plantbeneficial endophytic bacterium Bacillus subtilis HC8. Archives of microbiology 2012, 194 (11), $893-899$.

59. Touré, Y.; Ongena, M.; Jacques, P.; Guiro, A.; Thonart, P., Role of lipopeptides produced by Bacillus subtilis GA1 in the reduction of grey mould disease caused by Botrytis cinerea on apple. Journal of applied microbiology 2004, 96 (5), 1151-1160.

60. Gélis-Jeanvoine, S.; Canette, A.; Gohar, M.; Caradec, T.; Lemy, C.; Gominet, M.; Jacques, P.; Lereclus, D.; Slamti, L., Genetic and functional analyses of krs, a locus encoding kurstakin, a lipopeptide produced by Bacillus thuringiensis. Research in microbiology 2017, 168 (4), 356-368.

61. Das, P. K.; Das, S.; Sahoo, D.; Dalei, J.; Rao, V. M.; Nayak, S.; Palo, S., Comparative Evaluation of Purification Methods for Production of Polypeptide Antibiotics-"Polymyxin B" and "Cerexin A" from Bacillus Species. Pharma News 2021.

62. Hathout, Y.; Ho, Y.-P.; Ryzhov, V.; Demirev, P.; Fenselau, C., Kurstakins: a new class of Lipopeptides isolated from Bacillus thuringiensis. Journal of natural products 2000, 63 (11), 1492-1496.

63. Velkov, T.; Gallardo-Godoy, A.; Swarbrick, J. D.; Blaskovich, M. A.; Elliott, A. G.; Han, M.; Thompson, P. E.; Roberts, K. D.; Huang, J. X.; Becker, B., Structure, function, and biosynthetic origin of octapeptin antibiotics active against extensively drug-resistant Gram-negative bacteria. Cell chemical biology 2018, 25 (4), 380-391. e5.

64. Solecka, J.; Zajko, J.; Postek, M.; Rajnisz, A., Biologically active secondary metabolites from Actinomycetes. Open Life Sciences 2012, 7 (3), 373-390.

65. Dholakiya, R. N.; Kumar, R.; Mishra, A.; Mody, K. H.; Jha, B., Antibacterial and antioxidant activities of novel actinobacteria strain isolated from Gulf of Khambhat, Gujarat. Frontiers in microbiology 2017, 8, 2420.

66. Siddharth, S.; Vittal, R. R., Evaluation of antimicrobial, enzyme inhibitory, antioxidant and cytotoxic activities of partially purified volatile metabolites of marine Streptomyces sp. S2A. Microorganisms 2018, 6 (3), 72.

67. Dhakal, D.; Sohng, J. K.; Pandey, R. P., Engineering actinomycetes for biosynthesis of macrolactone polyketides. Microbial Cell Factories 2019, 18 (1), 137.

68. Widowati, I.; Zainuri, M.; Kusumaningrum, H. P.; Susilowati, R.; Hardivillier, Y.; Leignel, V.; Bourgougnon, N.; Mouget, J.-L. In Antioxidant activity of three microalgae Dunaliella salina, Tetraselmis chuii and Isochrysis galbana clone Tahiti, IOP Conference Series: Earth and Environmental Science, IOP Publishing: 2017; p 012067. 
69. McArthur, K. A.; Mitchell, S. S.; Tsueng, G.; Rheingold, A.; White, D. J.; Grodberg, J.; Lam, K. S.; Potts, B. C., Lynamicins $\mathrm{a}-\mathrm{e}$, chlorinated bisindole pyrrole antibiotics from a novel marine actinomycete. Journal of Natural Products 2008, 71 (10), 1732-1737.

70. Igarashi, Y.; Ogura, H.; Furihata, K.; Oku, N.; Indananda, C.; Thamchaipenet, A., Maklamicin, an antibacterial polyketide from an endophytic Micromonospora sp. Journal of natural products 2011, 74 (4), 670-674.

71. Zhang, J.; Wang, J.-D.; Liu, C.-X.; Yuan, J.-H.; Wang, X.-J.; Xiang, W.-S., A new prenylated indole derivative from endophytic actinobacteria Streptomyces sp. neau-D50. Natural Product Research 2014, 28 (7), 431-437.

72. Djinni, I.; Defant, A.; Kecha, M.; Mancini, I., Metabolite profile of marine-derived endophytic Streptomyces sundarbansensis WR 1 L 1 S 8 by liquid chromatography-mass spectrometry and evaluation of culture conditions on antibacterial activity and mycelial growth. Journal of applied microbiology 2014, 116 (1), 39-50.

73. Yang, X.; Peng, T.; Yang, Y.; Li, W.; Xiong, J.; Zhao, L.; Ding, Z., Antimicrobial and antioxidant activities of a new benzamide from endophytic Streptomyces sp. YIM 67086. Natural product research 2015, 29 (4), $331-335$.

74. Ding, W.-J.; Zhang, S.-Q.; Wang, J.-H.; Lin, Y.-X.; Liang, Q.-X.; Zhao, W.-J.; Li, C.-Y., A new di-O-prenylated flavone from an actinomycete Streptomyces sp. MA-12. Journal of asian natural products research 2013, 15 (2), $209-214$. 75. Lee, L.-H.; Zainal, N.; Azman, A.-S.; Eng, S.-K.; Goh, B.-H.; Yin, W.-F.; Ab Mutalib, N.-S.; Chan, K.-G., Diversity and antimicrobial activities of actinobacteria isolated from tropical mangrove sediments in Malaysia. The scientific world journal 2014, 2014.

76. Yang, X.; Yang, Y.; Peng, T.; Yang, F.; Zhou, H.; Zhao, L.; Xu, L.; Ding, Z., A new cyclopeptide from endophytic Streptomyces sp. YIM 64018. Natural product communications 2013, 8 (12), 1934578X1300801225.

77. Koller, M.; Muhr, A.; Braunegg, G., Microalgae as versatile cellular factories for valued products. Algal research 2014, 6, 52-63.

78. Li, Y.; Han, L.; Rong, H.; Li, L.; Zhao, L.; Wu, L.; Xu, L.; Jiang, Y.; Huang, X., Diastaphenazine, a new dimeric phenazine from an endophytic Streptomyces diastaticus subsp. ardesiacus. The Journal of Antibiotics 2015, 68 (3), $210-212$. 79. Savi, D. C.; Shaaban, K. A.; Vargas, N.; Ponomareva, L. V.; Possiede, Y. M.; Thorson, J. S.; Glienke, C.; Rohr, J., Microbispora sp. LGMB259 endophytic actinomycete isolated from Vochysia divergens (Pantanal, Brazil) producing $\beta$ carbolines and indoles with biological activity. Current microbiology 2015, 70 (3), 345-354.

80. Zhou, H.; Yang, Y.; Peng, T.; Li, W.; Zhao, L.; Xu, L.; Ding, Z., Metabolites of Streptomyces sp., an endophytic actinomycete from Alpinia oxyphylla. Natural Product Research 2014, 28 (4), 265-267.

81. Yan, L.-L.; Han, N.-N.; Zhang, Y.-Q.; Yu, L.-Y.; Chen, J.; Wei, Y.-Z.; Li, Q.-P.; Tao, L.; Zheng, G.-H.; Yang, S.-E., Antimycin A 18 produced by an endophytic Streptomyces albidoflavus isolated from a mangrove plant. The Journal of Antibiotics 2010, 63 (5), 259-261.

82. Manimaran, M.; Gopal, J. V.; Kannabiran, K., Antibacterial Activity of Streptomyces sp. VITMK1 Isolated from Mangrove Soil of Pichavaram, Tamil Nadu, India. Proceedings of the National Academy of Sciences, India Section B: Biological Sciences 2017, 87 (2), 499-506.

83. Wang, P.; Xi, L.; Liu, P.; Wang, Y.; Wang, W.; Huang, Y.; Zhu, W., Diketopiperazine derivatives from the marine-derived actinomycete Streptomyces sp. FXJ7.328. Mar Drugs 2013, 11 (4), 1035-49.

84. Kang, H.-K.; Hyun, C.-G., Anti-inflammatory effect of d-(+)-cycloserine through inhibition of NF- $\kappa B$ and MAPK signaling pathways in LPS-induced RAW 264.7 macrophages. Natural Product Communications 2020, 15 (4), 1934578 X20920481.

85. Robertsen, H. L.; Musiol-Kroll, E. M., Actinomycete-derived polyketides as a source of antibiotics and lead structures for the development of new antimicrobial drugs. Antibiotics 2019, 8 (4), 157.

86. Hug, J. J.; Bader, C. D.; Remškar, M.; Cirnski, K.; Müller, R., Concepts and methods to access novel antibiotics from actinomycetes. Antibiotics 2018, 7 (2), 44. 
87. Yu, Z.; Zhao, L.-X.; Jiang, C.-L.; Duan, Y.; Wong, L.; Carver, K. C.; Schuler, L. A.; Shen, B., Bafilomycins produced by an endophytic actinomycete Streptomyces sp. YIM56209. The Journal of antibiotics 2011, 64 (1), $159-162$. 88. Bulut, N.; Kocyigit, U. M.; Gecibesler, I. H.; Dastan, T.; Karci, H.; Taslimi, P.; Durna Dastan, S.; Gulcin, I.; Cetin, A., Synthesis of some novel pyridine compounds containing bis-1, 2, 4-triazole/thiosemicarbazide moiety and investigation of their antioxidant properties, carbonic anhydrase, and acetylcholinesterase enzymes inhibition profiles. Journal of biochemical and molecular toxicology 2018, 32 (1), e22006.

89. Gulcin, İ., Antioxidants and antioxidant methods: an updated overview. Archives of Toxicology 2020, 94 (3), 651715 .

90. Rodriguez-Valera, F.; Juez, G.; Kushner, D., Halocins: salt-dependent bacteriocins produced by extremely halophilic rods. Canadian Journal of Microbiology 1982, 28 (1), 151-154.

91. Gaglione, R.; Pirone, L.; Farina, B.; Fusco, S.; Smaldone, G.; Aulitto, M.; Dell'Olmo, E.; Roscetto, E.; Del Gatto, A.; Fattorusso, R.; Notomista, E.; Zaccaro, L.; Arciello, A.; Pedone, E.; Contursi, P., Insights into the anticancer properties of the first antimicrobial peptide from Archaea. Biochimica et Biophysica Acta (BBA) - General Subjects 2017, 1861 (9), 2155-2164.

92. Besse, A.; Peduzzi, J.; Rebuffat, S.; Carré-Mlouka, A., Antimicrobial peptides and proteins in the face of extremes: Lessons from archaeocins. Biochimie 2015, 118, 344-355.

93. Platas, G.; Meseguer, I.; Amils, R., Purification and biological characterization of halocin H1 from Haloferax mediterranei M2a. International Microbiology 2002, 5 (1), 15-19.

94. Meseguer, I.; Rodriguez-Valera, F., Production and purification of halocin H4. FEMS microbiology letters 1985, 28 (2), 177-182.

95. Torreblanca, M.; Meseguer, I.; Rodríguez-Valera, F., Halocin H6, a bacteriocin from Haloferax gibbonsii. Microbiology 1989, 135 (10), 2655-2661.

96. Li, Y.; Xiang, H.; Liu, J.; Zhou, M.; Tan, H., Purification and biological characterization of halocin C8, a novel peptide antibiotic from Halobacterium strain AS7092. Extremophiles 2003, 7 (5), 401-407.

97. Price, L. B.; Shand, R. F., Halocin S8: a 36-amino-acid microhalocin from the haloarchaeal strain S8a. Journal of bacteriology 2000, 182 (17), 4951-4958.

98. Ebert, K.; Goebel, W.; Rdest, U.; Surek, B., Genes and genome structures in the archaebacteria. Syst Appl Microbiol 1986, 7, 30-35.

99. Pašić, L.; Velikonja, B. H.; Ulrih, N. P., Optimization of the culture conditions for the production of a bacteriocin from halophilic archaeon Sech7a. Preparative biochemistry E biotechnology 2008, 38 (3), 229-245.

100. Shand, R. F.; Leyva, K. J., Peptide and protein antibiotics from the domain Archaea: halocins and sulfolobicins. In Bacteriocins, Springer: 2007; pp 93-109.

101. Karthikeyan, P.; Bhat, S. G.; Chandrasekaran, M., Halocin SH10 production by an extreme haloarchaeon Natrinema sp. BTSH10 isolated from salt pans of South India. Saudi journal of biological sciences 2013, 20 (2), $205-212$. 102. Wali, A. F.; Al Dhaheri, Y.; Ramakrishna Pillai, J.; Mushtaq, A.; Rao, P. G.; Rabbani, S. A.; Firdous, A.; Elshikh, M. S.; Farraj, D. A. A., Lc-ms phytochemical screening, in vitro antioxidant, antimicrobial and anticancer activity of microalgae Nannochloropsis oculata extract. Separations 2020, 7 (4), 54.

103. Tan, L. T.-H.; Chan, K.-G.; Khan, T. M.; Bukhari, S. I.; Saokaew, S.; Duangjai, A.; Pusparajah, P.; Lee, L.-H.; Goh, B.-H., Streptomyces sp. MUM212 as a Source of Antioxidants with Radical Scavenging and Metal Chelating Properties. Frontiers in Pharmacology 2017, 8 (276).

104. de Castro, I.; Mendo, S.; Caetano, T., Antibiotics from Haloarchaea: What Can We Learn from Comparative Genomics? Marine Biotechnology 2020, 22 (2), 308-316. 
105. Sahli, K.; Gomri, M. A.; Esclapez, J.; Gómez-Villegas, P.; Ghennai, O.; Bonete, M. J.; León, R.; Kharroub, K., Bioprospecting and characterization of pigmented halophilic archaeal strains from Algerian hypersaline environments with analysis of carotenoids produced by Halorubrum sp. BS2. Journal of Basic Microbiology 2020.

106. Ghanmi, F.; Carré-Mlouka, A.; Vandervennet, M.; Boujelben, I.; Frikha, D.; Ayadi, H.; Peduzzi, J.; Rebuffat, S.; Maalej, S., Antagonistic interactions and production of halocin antimicrobial peptides among extremely halophilic prokaryotes isolated from the solar saltern of Sfax, Tunisia. Extremophiles 2016, 20 (3), 363-374.

107. Ghanmi, F.; Carré-Mlouka, A.; Zarai, Z.; Mejdoub, H.; Peduzzi, J.; Maalej, S.; Rebuffat, S., The extremely halophilic archaeon Halobacterium salinarum ETD5 from the solar saltern of Sfax (Tunisia) produces multiple halocins. Research in Microbiology 2020, 171 (2), 80-90.

108. Besse, A.; Vandervennet, M.; Goulard, C.; Peduzzi, J.; Isaac, S.; Rebuffat, S.; Carré-Mlouka, A., Halocin C8: an antimicrobial peptide distributed among four halophilic archaeal genera: Natrinema, Haloterrigena, Haloferax, and Halobacterium. Extremophiles 2017, 21 (3), 623-638.

109. Quehenberger, J.; Shen, L.; Albers, S.-V.; Siebers, B.; Spadiut, O., Sulfolobus - A Potential Key Organism in Future Biotechnology. Frontiers in Microbiology 2017, 8 (2474).

110. Roscetto, E.; Contursi, P.; Vollaro, A.; Fusco, S.; Notomista, E.; Catania, M. R., Antifungal and anti-biofilm activity of the first cryptic antimicrobial peptide from an archaeal protein against Candida spp. clinical isolates. Scientific Reports 2018, 8 (1), 17570.

111. Kumar, V.; Tiwari, S. K., Activity-guided separation and characterization of new halocin HA3 from fermented broth of Haloferax larsenii HA3. Extremophiles 2017, 21 (3), 609-621.

112. Quadri, I.; Hassani, I. I.; l'Haridon, S.; Chalopin, M.; Hacène, H.; Jebbar, M., Characterization and antimicrobial potential of extremely halophilic archaea isolated from hypersaline environments of the Algerian Sahara.

Microbiological Research 2016, 186-187, 119-131.

113. Photolo, M. M.; Mavumengwana, V.; Sitole, L.; Tlou, M. G., Antimicrobial and Antioxidant Properties of a Bacterial Endophyte, Methylobacterium radiotolerans MAMP 4754, Isolated from Combretum erythrophyllum Seeds. International Journal of Microbiology 2020, 2020, 9483670.

114. Ayyanna, R.; Ankaiah, D.; Arul, V., Anti-inflammatory and Antioxidant Properties of Probiotic Bacterium Lactobacillus mucosae AN1 and Lactobacillus fermentum SNR1 in Wistar Albino Rats. Frontiers in Microbiology 2018, 9 (3063).

115. Revilla, G.; Ramos, F.; López-Nieto, M.; Alvarez, E.; Martin, J., Glucose represses formation of delta-(L-alphaaminoadipyl)-L-cysteinyl-D-valine and isopenicillin N synthase but not penicillin acyltransferase in Penicillium chrysogenum. Journal of bacteriology 1986, 168 (2), 947-952.

116. Zanca, D. M.; Martin, J. F., Carbon catabolite regulation of the conversion of penicillin $\mathrm{N}$ into cephalosporin C. The Journal of antibiotics 1983, 36 (6), 700-708.

117. Malve, H., Exploring the ocean for new drug developments: Marine pharmacology. Journal of pharmacy $\mathcal{E}$ bioallied sciences 2016, 8 (2), 83.

118. Li, Y.; Lan, N.; Xu, L.; Yue, Q., Biosynthesis of pneumocandin lipopeptides and perspectives for its production and related echinocandins. Applied Microbiology and Biotechnology 2018, 102 (23), 9881-9891.

119. Huang, Z.; Cai, X.; Shao, C.; She, Z.; Xia, X.; Chen, Y.; Yang, J.; Zhou, S.; Lin, Y., Chemistry and weak antimicrobial activities of phomopsins produced by mangrove endophytic fungus Phomopsis sp. ZSU-H76. Phytochemistry 2008, 69 (7), 1604-1608.

120. Strobel, G.; Daisy, B., Bioprospecting for microbial endophytes and their natural products. Microbiology and molecular biology reviews 2003, 67 (4), 491-502. 
121. Liu, H.; Yan, C.; Li, C.; You, T.; She, Z., Naphthoquinone derivatives with anti-inflammatory activity from mangrove-derived endophytic fungus Talaromyces sp. SK-S009. Molecules 2020, 25 (3), 576.

122. Zhang, C.-L.; Zheng, B.-Q.; Lao, J.-P.; Mao, L.-J.; Chen, S.-Y.; Kubicek, C. P.; Lin, F.-C., Clavatol and patulin formation as the antagonistic principle of Aspergillus clavatonanicus, an endophytic fungus of Taxus mairei. Applied microbiology and biotechnology 2008, 78 (5), 833-840.

123. Wu, S.-H.; Chen, Y.-W.; Shao, S.-C.; Wang, L.-D.; Li, Z.-Y.; Yang, L.-Y.; Li, S.-L.; Huang, R., Ten-membered lactones from Phomopsis sp., an endophytic fungus of Azadirachta indica. Journal of natural products 2008, 71 (4), $731-734$. 124. Toghueo, R. M. K.; Sahal, D.; Boyom, F. F., Recent advances in inducing endophytic fungal specialized metabolites using small molecule elicitors including epigenetic modifiers. Phytochemistry 2020, 174, 112338.

125. Liu, Y.; Mándi, A.; Li, X.-M.; Meng, L.-H.; Kurtán, T.; Wang, B.-G., Peniciadametizine a, a dithiodiketopiperazine with a unique spiro [furan-2, 7'-pyrazino [1, 2-b][1, 2] oxazine] skeleton, and a related analogue, peniciadametizine B, from the marine sponge-derived fungus Penicillium adametzioides. Marine drugs 2015, 13 (6), 3640-3652.

126. Meng, L.-H.; Zhang, P.; Li, X.-M.; Wang, B.-G., Penicibrocazines A-E, five new sulfide diketopiperazines from the marine-derived endophytic fungus Penicillium brocae. Marine drugs 2015, 13 (1), 276-287.

127. Wu, B.; Wiese, J.; Labes, A.; Kramer, A.; Schmaljohann, R.; Imhoff, J. F., Lindgomycin, an unusual antibiotic polyketide from a marine fungus of the Lindgomycetaceae. Marine drugs 2015, 13 (8), 4617-4632.

128. Gao, S.-S.; Li, X.-M.; Du, F.-Y.; Li, C.-S.; Proksch, P.; Wang, B.-G., Secondary metabolites from a marine-derived endophytic fungus Penicillium chrysogenum QEN-24S. Marine drugs 2011, 9 (1), 59-70.

129. Wang, C.; Tang, S.; Cao, S., Antimicrobial compounds from marine fungi. Phytochemistry Reviews 2020, 1-33.

130. Li, X.; Li, X.-M.; Zhang, P.; Wang, B.-G., A new phenolic enamide and a new meroterpenoid from marine algaderived endophytic fungus Penicillium oxalicum EN-290. Journal of Asian Natural Products Research 2015, 17 (12), 12041212.

131. Liu, H.; Li, X.-M.; Liu, Y.; Zhang, P.; Wang, J.-N.; Wang, B.-G., Chermesins A-D: Meroterpenoids with a drimane-type spirosesquiterpene skeleton from the marine algal-derived endophytic fungus Penicillium chermesinum EN-480. Journal of natural products 2016, 79 (4), 806-811.

132. Gao, S.-S.; Li, X.-M.; Zhang, Y.; Li, C.-S.; Cui, C.-M.; Wang, B.-G., Comazaphilones A- F, azaphilone derivatives from the marine sediment-derived fungus Penicillium commune QSD-17. Journal of natural products 2011, 74 (2), $256-261$. 133. Meng, L.-H.; Li, X.-M.; Liu, Y.; Wang, B.-G., Penicibilaenes A and B, sesquiterpenes with a tricyclo [6.3. 1.01, 5] dodecane skeleton from the marine isolate of Penicillium bilaiae MA-267. Organic letters 2014, 16 (23), $6052-6055$.

134. Fukuda, T.; Kurihara, Y.; Kanamoto, A.; Tomoda, H., Terretonin G, a new sesterterpenoid antibiotic from marine-derived Aspergillus sp. OPMF00272. The Journal of Antibiotics 2014, 67 (8), 593-595.

135. Prompanya, C.; Dethoup, T.; Bessa, L. J.; Pinto, M. M.; Gales, L.; Costa, P. M.; Silva, A.; Kijjoa, A., New isocoumarin derivatives and meroterpenoids from the marine sponge-associated fungus Aspergillus similanensis sp. nov. KUFA 0013. Marine drugs 2014, 12 (10), 5160-5173.

136. Ding, L.; Li, T.; Liao, X.; He, S.; Xu, S., Asperitaconic acids A-C, antibacterial itaconic acid derivatives produced by a marine-derived fungus of the genus Aspergillus. The Journal of antibiotics 2018, 71 (10), 902-904.

137. Peng, X.; Wang, Y.; Zhu, T.; Zhu, W., Pyrazinone derivatives from the coral-derived Aspergillus ochraceus LCJ11102 under high iodide salt. Archives of Pharmacal Research 2018, 41 (2), 184-191.

138. Wang, R.; Guo, Z. K.; Li, X. M.; Chen, F. X.; Zhan, X. F.; Shen, M. H., Spiculisporic acid analogues of the marinederived fungus, Aspergillus candidus strain HDf2, and their antibacterial activity. Antonie van Leeuwenhoek 2015, 108 (1), 215-219.

139. Zhu, F.; Chen, G.; Chen, X.; Huang, M.; Wan, X., Aspergicin, a new antibacterial alkaloid produced by mixed fermentation of two marine-derived mangrove epiphytic fungi. Chemistry of Natural Compounds 2011, 47 (5), $767-769$. 
140. Zhang, Y.; Wang, S.; Li, X.-M.; Cui, C.-M.; Feng, C.; Wang, B.-G., New sphingolipids with a previously unreported 9-methyl-C 20-sphingosine moiety from a marine algous endophytic fungus Aspergillus niger EN-13. Lipids 2007, 42 (8), 759-764.

141. Yang, G.; Sandjo, L.; Yun, K.; Leutou, A. S.; Kim, G.-D.; Choi, H. D.; Kang, J. S.; Hong, J.; Son, B. W., Flavusides A and B, antibacterial cerebrosides from the marine-derived fungus Aspergillus flavus. Chemical and Pharmaceutical Bulletin 2011, 59 (9), 1174-1177.

142. Hawas, U. W.; El-Beih, A. A.; El-Halawany, A. M., Bioactive anthraquinones from endophytic fungus Aspergillus versicolor isolated from red sea algae. Archives of pharmacal research 2012, 35 (10), 1749-1756.

143. Li, H.-L.; Li, X.-M.; Yang, S.-Q.; Cao, J.; Li, Y.-H.; Wang, B.-G., Induced terreins production from marine red algal-derived endophytic fungus Aspergillus terreus EN-539 co-cultured with symbiotic fungus Paecilomyces lilacinus EN-531. The Journal of antibiotics 2020, 73 (2), 108.

144. Cao, C. W. S. T. S., Antimicrobial compounds from marine fungi. Phytochem Reviews 2020.

145. Zhu, A.; Yang, M.-Y.; Zhang, Y.-H.; Shao, C.-L.; Wang, C.-Y.; Hu, L.-D.; Cao, F.; Zhu, H.-J., Absolute configurations of 14,15-hydroxylated prenylxanthones from a marine-derived Aspergillus sp. fungus by chiroptical methods. Scientific reports 2018, 8 (1), 1-10.

146. Liu, Z.; Dong, Z.; Qiu, P.; Wang, Q.; Yan, J.; Lu, Y.; Wasu, P.-a.; Hong, K.; She, Z., Two new bioactive steroids from a mangrove-derived fungus Aspergillus sp. Steroids 2018, 140, 32-38.

147. Pruksakorn, P.; Arai, M.; Kotoku, N.; Vilchèze, C.; Baughn, A. D.; Moodley, P.; Jacobs Jr, W. R.; Kobayashi, M., Trichoderins, novel aminolipopeptides from a marine sponge-derived Trichoderma sp., are active against dormant mycobacteria. Bioorganic \& medicinal chemistry letters 2010, 20 (12), 3658-3663.

148. Pang, X.; Lin, X.; Yang, J.; Zhou, X.; Yang, B.; Wang, J.; Liu, Y., Spiro-phthalides and isocoumarins isolated from the marine-sponge-derived fungus Setosphaeria sp. SCSIO41009. Journal of natural products 2018, 81 (8), $1860-1868$. 149. Song, T.; Chen, M.; Chai, W.; Zhang, Z.; Lian, X.-Y., New bioactive pyrrospirones C-I from a marine-derived fungus Penicillium sp. ZZ380. Tetrahedron 2018, 74 (8), 884-891.

150. Song, T.; Chen, M.; Ge, Z.-W.; Chai, W.; Li, X.-C.; Zhang, Z.; Lian, X.-Y., Bioactive penicipyrrodiether A, an adduct of GKK1032 analogue and phenol A derivative, from a marine-sourced fungus Penicillium sp. ZZ380. The Journal of organic chemistry 2018, 83 (21), 13395-13401.

151. Shen, H.-S.; Shao, S.; Chen, J.-C.; Zhou, T., Antimicrobials from Mushrooms for Assuring Food Safety. Comprehensive Reviews in Food Science and Food Safety 2017, 16 (2), 316-329.

152. Thu, Z. M.; Myo, K. K.; Aung, H. T.; Clericuzio, M.; Armijos, C.; Vidari, G., Bioactive Phytochemical Constituents of Wild Edible Mushrooms from Southeast Asia. Molecules 2020, 25 (8), 1972.

153. Mygind, P. H.; Fischer, R. L.; Schnorr, K. M.; Hansen, M. T.; Sönksen, C. P.; Ludvigsen, S.; Raventós, D.; Buskov, S.; Christensen, B.; De Maria, L.; Taboureau, O.; Yaver, D.; Elvig-Jørgensen, S. G.; Sørensen, M. V.; Christensen, B. E.; Kjærulff, S.; Frimodt-Moller, N.; Lehrer, R. I.; Zasloff, M.; Kristensen, H.-H., Plectasin is a peptide antibiotic with therapeutic potential from a saprophytic fungus. Nature 2005, 437 (7061), 975-980.

154. Wong, J. H.; Ng, T. B.; Wang, H.; Sze, S. C. W.; Zhang, K. Y.; Li, Q.; Lu, X., Cordymin, an antifungal peptide from the medicinal fungus Cordyceps militaris. Phytomedicine 2011, 18 (5), 387-392.

155. Gebreyohannes, G.; Nyerere, A.; Bii, C.; Sbhatu, D. B., Investigation of antioxidant and antimicrobial activities of different extracts of Auricularia and Termitomyces species of mushrooms. The Scientific World Journal $2019,2019$.

156. Poompouang, S.; Suksomtip, M., Isolation and characterization of an antifungal peptide from fruiting bodies of edible mushroom Lentinus squarrosulus Mont. Malaysian Journal of Microbiology 2016, 12 (1), 43-49. 
157. Irshad, A.; Sarwar, N.; Sadia, H.; Malik, K.; Javed, I.; Irshad, A.; Afzal, M.; Abbas, M.; Rizvi, H., Comprehensive facts on dynamic antimicrobial properties of polysaccharides and biomolecules-silver nanoparticle conjugate. International Journal of Biological Macromolecules 2020, 145, 189-196.

158. Hamamoto, E.; Kimura, N.; Nishino, S.; Ishihara, A.; Otani, H.; Osaki-Oka, K., Antimicrobial activity of the volatile compound 3,5-dichloro-4-methoxybenzaldehyde, produced by the mushroom Porostereum spadiceum, against plant-pathogenic bacteria and fungi. Journal of Applied Microbiology n/a (n/a).

159. Subrata, G.; Gunjan, B.; Prakash, P.; Mandal, S. C.; Krishnendu, A., Antimicrobial activities of basidiocarps of wild edible mushrooms of West Bengal, India. International Journal of PharmTech Research 2012, 4 (4), $1554-1560$.

160. Sevindi, M., Phenolic content, antioxidant and antimicrobial potential of Melanoleuca melaleuca edible mushroom. The Journal of Animal \& Plant Sciences, 2021, 31 (3), 824-830.

161. Endo, H.; Niioka, M.; Kobayashi, N.; Tanaka, M.; Watanabe, T., Butyrate-producing probiotics reduce nonalcoholic fatty liver disease progression in rats: new insight into the probiotics for the gut-liver axis. PloS one 2013, 8 (5), e63388.

162. Fakruddin, M.; Hossain, M. N.; Ahmed, M. M., Antimicrobial and antioxidant activities of Saccharomyces cerevisiae IFST062013, a potential probiotic. BMC Complementary and Alternative Medicine 2017, 17 (1), 64.

163. Breinig, F.; Sendzik, T.; Eisfeld, K.; Schmitt, M. J., Dissecting toxin immunity in virus-infected killer yeast uncovers an intrinsic strategy of self-protection. Proceedings of the National Academy of Sciences 2006, 103 (10), $3810-3815$. 164. Muccilli, S.; Wemhoff, S.; Restuccia, C.; Meinhardt, F., Exoglucanase-encoding genes from three Wickerhamomyces anomalus killer strains isolated from olive brine. Yeast 2013, 30 (1), 33-43.

165. Gao, D.; Gao, Z.; Zhu, G., Antioxidant effects of Lactobacillus plantarum via activation of transcription factor Nrf2. Food $\mathcal{E}$ function 2013, 4 (6), 982-989.

166. Diao, Y.; Xin, Y.; Zhou, Y.; Li, N.; Pan, X.; Qi, S.; Qi, Z.; Xu, Y.; Luo, L.; Wan, H., Extracellular polysaccharide from Bacillus sp. strain LBP32 prevents LPS-induced inflammation in RAW 264.7 macrophages by inhibiting NF- $\kappa B$ and MAPKs activation and ROS production. International immunopharmacology 2014, 18 (1), 12-19.

167. Molino, A.; Iovine, A.; Casella, P.; Mehariya, S., Microalgae Characterization for Consolidated and New Application in Human Food, Animal Feed and Nutraceuticals. International Journal of Environmental Research and Public Health 2018, 15 (11).

168. Moreno-Garcia, L.; Adjallé, K.; Barnabé, S.; Raghavan, G., Microalgae biomass production for a biorefinery system: recent advances and the way towards sustainability. Renewable and Sustainable Energy Reviews 2017, 76, 493506.

169. Desbois, A. P.; Mearns-Spragg, A.; Smith, V. J., A fatty acid from the diatom Phaeodactylum tricornutum is antibacterial against diverse bacteria including multi-resistant Staphylococcus aureus (MRSA). Marine Biotechnology 2009, $11(1), 45-52$.

170. Arguelles, E., Proximate analysis, antibacterial activity, total phenolic content and antioxidant capacity of a green microalga Scenedesmus quadricauda (Turpin) Brébisson. Asian Journal of Microbiology, Biotechnology and Environmental Sciences 2018, 20, 150-158.

171. Maadane, A.; Merghoub, N.; Mernissi, N. E.; Ainane, T.; Amzazi, S.; Bakri, I. W., Antimicrobial activity of marine microalgae isolated from Moroccan coastlines. Journal of Microbiology, Biotechnology and Food Sciences 2020, 9 (5), 1257-1260.

172. Zielinski, D.; Fraczyk, J.; Debowski, M.; Zielinski, M.; Kaminski, Z. J.; Kregiel, D.; Jacob, C.; Kolesinska, B., Biological activity of hydrophilic extract of Chlorella vulgaris grown on post-fermentation leachate from a biogas plant supplied with stillage and maize silage. Molecules 2020, 25 (8), 1790. 
173. Alsenani, F.; Tupally, K. R.; Chua, E. T.; Eltanahy, E.; Alsufyani, H.; Parekh, H. S.; Schenk, P. M., Evaluation of microalgae and cyanobacteria as potential sources of antimicrobial compounds. Saudi Pharmaceutical Journal 2020, 28 (12), 1834-1841.

174. Maadane, A.; Merghoub, N.; Mernissi, N. E.; Ainane, T.; Amzazi, S.; Bakri, I. W., Antimicrobial activity of marine microalgae isolated from Moroccan coastlines. Journal of Microbiology, Biotechnology and Food Sciences 2021, 2021, 1257-1260.

175. Washida, K.; Koyama, T.; Yamada, K.; Kita, M.; Uemura, D., Karatungiols A and B, two novel antimicrobial polyol compounds, from the symbiotic marine dinoflagellate Amphidinium sp. Tetrahedron letters 2006, 47 (15), 25212525.

176. Ghaidaa, H.; Neihaya, H.; Nada, Z. M.; Amna, M., The Biofilm Inhibitory Potential of Compound Produced from Chlamydomonas reinhardtii Against Pathogenic Microorganisms. Baghdad Science Journal 2020, 17 (1).

177. Pratt, R.; Daniels, T.; Eiler, J. J.; Gunnison, J.; Kumler, W.; Oneto, J. F.; Strait, L. A.; Spoehr, H.; Hardin, G.; Milner, H., Chlorellin, an antibacterial substance from Chlorella. Science (Washington) 1944, 351-2.

178. Bancalari, E.; Martelli, F.; Bernini, V.; Neviani, E.; Gatti, M., Bacteriostatic or bactericidal? Impedometric measurements to test the antimicrobial activity of Arthrospira platensis extract. Food Control 2020, 118, 107380.

179. Guzmán, F.; Wong, G.; Román, T.; Cárdenas, C.; Alvárez, C.; Schmitt, P.; Albericio, F.; Rojas, V., Identification of antimicrobial peptides from the microalgae Tetraselmis suecica (Kylin) Butcher and bactericidal activity improvement. Marine drugs 2019, 17 (8), 453.

180. Mendiola, J. A.; Torres, C. F.; Toré, A.; Martín-Álvarez, P. J.; Santoyo, S.; Arredondo, B. O.; Señoráns, F. J.; Cifuentes, A.; Ibáñez, E., Use of supercritical CO 2 to obtain extracts with antimicrobial activity from Chaetoceros muelleri microalga. A correlation with their lipidic content. European Food Research and Technology 2007, 224 (4), 505-510. 181. Kokou, F.; Makridis, P.; Kentouri, M.; Divanach, P., Antibacterial activity in microalgae cultures. Aquaculture Research 2012, 43 (10), 1520-1527.

182. Blunt, J. W.; Copp, B. R.; Keyzers, R. A.; Munro, M. H.; Prinsep, M. R., Marine natural products. Natural Product Reports 2015, 32 (2), 116-211.

183. Sanzo, G. D.; Mehariya, S.; Martino, M.; Larocca, V.; Casella, P.; Chianese, S.; Musmarra, D.; Balducchi, R.; Molino, A., Supercritical carbon dioxide extraction of astaxanthin, lutein, and fatty acids from Haematococcus pluvialis microalgae. Marine drugs 2018, 16 (9), 334. 